\title{
An Empirical Investigation of the Twin Deficit Hypothesis: \\ Evidence from Sri Lanka
}

\author{
Anil Perera
}

and

Erandi Liyanage

\begin{abstract}
Theoretical and empirical evidence proves that prolonged fiscal expansions contribute to current account imbalances and hence, there exists a positive-long run relationship between budget deficits and current account deficits. This relationship is referred to as 'twin deficit hypothesis.' Significant fiscal expansions and external imbalances, which caused macroeconomic instability in a large number of advanced countries and emerging countries, have motivated examining the issue of twin deficits. Like many other emerging countries, for a long period of time, Sri Lankan economy has been experiencing persistently high budget deficits and current account deficits. In this study, we attempt to explore the twin deficit hypothesis interacting with key financial variables using both annual and quarterly data for Sri Lanka and employing multivariate empirical methodology. We find evidence for long run relationships between twin deficits in Sri Lanka. At the same time, we detect unidirectional causation between twin deficits, which enables into draw several policy implications.
\end{abstract}

Key Words: Twin Deficits, Cointegration, Granger Causality JEL classification : E2, E4, E6, F32, H62

\footnotetext{
Authors would like to acknowledge the support of Mr. K.D Ranasinghe, Mr. D. Kumaratunge, Mr. Sunil Ratnasiri, Dr. M.Z.M. Aazim, Ms. Dimuthu Samaratunga, Mr. Udeni Thilakaratne, Mr. Asanka Rubasinghe and Mr. Waruna Wikumsiri of Central Bank of Sri Lanka and Ms. Ameesha Wijayatunga in the Philippines. Authors would also like to thank the anonymous referee for insightful comments and useful suggestions. Any remaining errors and omissions are the responsibility of the authors.

Correspondence: Anil Perera: anilraa@cbsl.lk/anil.perera@monash.edu;

Erandi Liyange: erah@cbsl.lk/erandi_hasi@yahoo.com.
} 


\section{Introduction}

The budget deficits (defined as total government expenditures minus total tax revenues) and the current account deficits (defined as the difference between revenues and costs from trade plus net transfers to the country) are considered as major macroeconomic concerns in any economy. It has been argued that maintaining sustainable budget deficits as one of the major pre-conditions for an economy to thrive. At the same time, large current account deficits assumed to be one of the major macroeconomic ailments, which jeopardises the external stability in particular and the macroeconomic stability in general.

According to open economy macroeconomics, a government budget deficit leads to a current account deficit and this phenomenon is termed the twin deficits hypothesis (TDH) (Salvatore, 2006). Accordingly, TDH contends that there is a strong positive relationship between a national economy's current account balance of the balance of payments (BOP) and government budget balance. The theoretical explanation for the TDH is based on the well-known Mundell-Fleming (Fleming, 1962; Mundell, 1963) framework. According to this model, an increase in budget deficit induces upward pressure on interest rates that in turn trigger capital inflows and appreciation of the exchange rate. In particular, a debt financed expansionary fiscal policy raises the interest rates and given that most countries adopt a free capital movement policy, the rise in interest rate makes it attractive for investors to investments in that country's financial market. This raises the demand for the country's currency causing it to appreciate which would in turn make imports cheaper and exports more expensive relative to the prices of foreign goods. Hence, the appreciation of the domestic currency will lead to an increase in imports and ultimately in current account deficit (Leachman and Francis, 2002; Salvatore, 2006). In sum, a fiscal expansion, i.e., an increase in fiscal deficit raises output and thus imports creating a trade deficit and ultimately a current account imbalance with the appreciation of exchange rate (Blanchard and Sheen 2009).

The relationship between deficits in the external current account and the government fiscal account has important policy implications for a number of reasons. First, persistent large deficits cause indebtedness due to borrowing internally and externally and hence, impose a burden on future generations (Harko, 2009). At the same time, current account deficits coupled with increases in budget deficits and resultant inflation could lower the country's sovereign ratings and trigger a capital flight while creating difficulties on external financing. Also, growing fiscal and current account imbalances cause macroeconomic imbalances and hence, affect long-term economic progress of a country (Baharumshah, Lau and Khalid, 2006). 
In this context, establishing and understanding the relationship between twin deficits would help to formulate appropriate macroeconomic policies for a country. Particularly, if the views with regard to the causal role of the budget deficit are incorrect, then simple reductions in budget deficits may not resolve current account imbalances. Also, as a result, scarce economic resources will be diverted from relevant and urgently needed policy options (Belongia and Stone, 1985). To that end, investigating the relationship between these two deficits appears to be much important.

In economic literature, two prime approaches are known to have explored the relationship between the current account deficit and budget deficit of a country: the conventional Keynesian preposition and the Ricardian Equivalence.

Based on the Mundell-Fleming framework, Keynesian proposition argues that the budget deficit does have a significant impact on the current account deficit. If the budget is in deficit, then the government have to borrow money from private sector or from other countries. This leads to crowd-out some private borrowing. Then total national saving which is the sum of private saving plus the government fiscal balance will decrease. With a lower level of national savings, the interest rates should increase leading to an appreciation in the exchange rate triggering foreign inflows. The appreciation of domestic currency will make exports less attractive and imports more attractive, subsequently worsening the trade balance, which is the major component in the current account deficit. Hence, the Keynesian absorption theory suggests that an increase in budget deficit would induce domestic absorption and import expansion causing an increase or worsening in current account (Kouassi, Mougoue' and Kymn, 2004). As per these theoretical arguments, the Keynesian proposition can be summarised as follows. First, a positive relationship exists between current account and budget deficits. Second, there exists a unidirectional Granger causality that runs from budget deficit to current account deficit (Baharumshah, Ismail and Lau, 2009). Accordingly, the TDH states that a budget deficit will lead to a current account deficit and a budget surplus will improve the current account deficit.

The Ricardian Equivalence Hypothesis (REH) claims an absence of any relationship between the current account deficit and budget deficit (Barro, 1974 and 1989; Buchanan 1976).This approach reveals that shifts between taxes and budget deficits do not impact the real interest rate, the quantity of investment, or the current account balance. The effect of the present tax cut or increase in government expenditure does not alter the mix of current consumption and investment since rational agents foresee the present tax cut as a tax burden in future. Therefore, they will increase savings in order to pay for 
future tax increases. Hence, as Ricardian reveals the tax cut is considered as a temporary procedure. The decrease of public saving will be compensated for by an equal increase of private saving, and hence the national saving will not be affected. In other words, the absence of any causal relationship between the two deficits is in accordance with the REH.

Although previous literature mainly focused the discussions on the twin deficits based on these two major theoretical models, these are not the only possible outcomes between the two deficits. In fact, there are four testable hypotheses arising from the twin deficits phenomena. First, causality runs from budget deficit to current account deficit. Second, an absence of any relationship between the two deficits is also possible, indicating these deficits are independent. Third, a unidirectional causality, which runs from current account to budgetary variable also, may exist. Finally, a bi-directional causality between the two deficits could also exit (Mukhtar, Zakaria and Ahmed, 2007; Baharumshah et al., 2009).

For a long period of time, researchers and policy makers have been concerned over the state of the current account and budgetary imbalances. Particularly, a renewed interest on twin deficits can be observed during last twenty years. For example, Taylor (2002) discusses the developments of current account deficits over a period of about 120 years and shows that external imbalances have been an important feature of the world economy, although their role has changed several times. At the same time, Frankel (2004) argues that the fiscal policy of the current decade in many respects mirrors the fiscal policy of the 1980s and growing budget deficits are reflected in growing current account deficits.

The discussion over TDH is motivated by the emergence of twin deficits mainly in the US economy (Normandin, 1999; Mann, 2002). However, the close connection between current account and budget deficits was not unique to the economy of the United States. Europe, Germany and Sweden faced similar problems in the early part of the 1990s when the rise in the budget deficits was accompanied by a real appreciation of their national currencies that adversely affected the current accounts (Ibrahim and Kumah, 1996). Such growing fiscal and current account imbalances have been considered as the major cause of macroeconomic imbalances and instability in many countries (for example: Edwards, 2001).

On the other hand, many argue that the experiences in emerging countries in regards to twin deficits are very different from that of developed countries. For example, 
Anoruo and Ramchander (1998) argue that there could be wide disparities in emerging countries in the macroeconomic dynamics governing fiscal and current account deficits due to inefficient public enterprises, deficient infrastructure, tight trade controls, regulations in the financial sector and political uncertainty.

In the late 1970s, many emerging/developing countries were running large budget deficits to finance large and growing government spending and in order to finance these deficits, governments borrowed heavily in global capital markets. The large and growing budget deficits led to significant current account imbalances and the accumulation of large stocks of foreign debt (Baharumshah et al., 2009). Accordingly, most developing countries experienced problems with external debts in the early 1980s as a result of weak fiscal positions due to unsustainable budget deficits. This has led the discussion on TDH and it was argued that the relationship between budget deficits and current account deficits is even much stronger in developing economies (for example: Laney, 1984). Since 1980s, the discussion on twin deficits in these countries has been continued into recent decades (for example: Anoruo and Ramchander, 1998; Khalid and Teo, 1999; Lau and Baharumshah, 2006). Given the importance of emerging countries in the present global economic context, further investigation on the TDH in emerging countries remains significant and timely.

Like many other developing countries, for a long period of time, Sri Lanka has experienced persistently high budget deficits as well as current account deficits. This issue has received some attention of International Monetary Fund and the World Bank (Saleh, Nair and Agalewatte, 2005). However, the issue of TDH for Sri Lanka has been explicitly examined only in a few occasions although there are some attempts to explore the issue with regard to budget deficits and related issues in Sri Lanka (for example: Colombage, 1991). Moreover, Saleh et al. (2005) examined TDH for Sri Lanka only by concentrating on the relationship between current account imbalance and budget deficit. Meanwhile, Chowdhury and Saleh (2008) study the current account and budget deficit relationship for Sri Lanka in the presence of saving and investment gap and trade openness. Both these studies support the Keynesian view and hence, confirm the existence of TDH for Sri Lanka. These attempts are extremely important in understanding the link between twin deficits; however, there still remains a significant research gap in regards to twin deficits in Sri Lanka. Accordingly, the overall goal of this study is to revisit the issue since a careful and critical assessment of twin deficits would help to deepen the understanding of macroeconomic dynamics of the Sri Lankan economy and hence, formulate better calibrated macroeconomic policies. 
This study however differs from the existing literature in the following ways. First, this study attempts to examine the TDH for Sri Lanka including most important financial variables such as interest rates and exchange rates, which are known to influence the twin deficits process. On the one hand, this is important as the discussion surrounding deficits and interest rates has been controversial (Abell 1990). On the other hand, the endogeneity of two deficit variables in many countries warrants investigating the indirect causality that may exist in the twin deficits nexus by way of including the role of the causing variables, i.e. interest and exchange rates (Baharumshah et al., 2006). However, existing studies for Sri Lanka do not consider the direct or indirect effects of deficits via other variables such as interest rates and exchange rates on the deficits, etc. ${ }^{1}$ However, probe into TDH requires explicit examination of the most relevant set of variables that may relate meaningfully to fiscal and external balance relations. Second, previous studies use annual data, but we resort to both annual and quarterly data in order to capture the dynamics of variables that could omit when using annual time series data.

Hence, to shed further insight on the twin deficit issue in Sri Lanka, this study addresses the following two questions: (i) Is there a strong relationship between budget deficits and current account deficits in Sri Lanka? (ii) What is the impact of interest rates and exchange rates in the budget deficits and current account deficits nexus?

The remainder of the paper is organised as follows: Section 2 presents the theoretical framework of the TDH while Section 3 contains relevant empirical evidence. Section 4 briefly elaborates on the developments in twin deficits in Sri Lanka. Section 5 outlines econometric models used to assess the TDH. Section 6 contains empirical findings and the discussion and Section 7 concludes the study.

\section{Theoretical Underpinnings of Twin Deficit Hypothesis}

The connection between the budget deficit and current account deficit can be derived from the national account identity:

1 Baharumshah and Lau (2006) investigate twin deficits for a panel of South East Asian Central Banks (SEACEN) countries including Sri Lanka and consider the role of the two financial variables. However, as the investigation is based on panel data analysis, they do not explicitly provide evidence for Sri Lanka. Saleh and Chowdhury (2008) consider financial variables using a surrogate variable of openness $[(\mathrm{X}+\mathrm{M}) / \mathrm{Y}]$ in order to capture the combined effect of exchange rate and interest rate. 


$$
G N P=C+I p+G+(X-M)
$$

GNP is gross national product, which is the sum of private consumption (C), private investment $(I p)$, government expenditure on goods and services $(G)$ and exports $(X)$. Imports $(M)$ are treated as a negative component to avoid double counting of consumption or investment of good purchased domestically, but produced abroad. $(X-M)$ represents net exports plus net factor income, i.e. current account balance of balance of payments.

GNP is simply the sum of the income received by all individuals in the economy. Hence, an individual has four possible uses of this income; it can be consumed $(C)$, saved $(S p)$, paid in taxes $(T)$ or transferred abroad $(T r)$. Accordingly, equation (1) can be written as;

$$
G N P=C+S p+T G+T r
$$

By equating the two expressions for GNP specified above and also rearranging terms, the following equation can be derived to highlight the relationship between budget deficits and current account deficits.

$$
X-M-T r=(T-G)+(S p-I p)
$$

where, $\quad X-M-T r=C A$

$C A$ is current account balance. Hence, the relationships in equations (3) and (4) can be interpreted to state that current account balance is equal to the surplus of private saving over investment and the gap between government tax receipts and government expenditures on goods and services, that is, the government budget balance. ${ }^{2}$ Hence,

$$
C A=B D+S D
$$

2 Equation (3) is useful in a number of ways. It shows that, for a given savings rate, a budget deficit will either crowd out private investment or lead to an inflow of foreign capital (or both). By definition, anything that affects budget deficits, investment, or savings, in turn, affects both capital flows and the trade deficit (Abell, 1990). 
where, $C A$ represent the net exports plus net factor income (current account balance), $B D$ is the budget deficit, representing the difference between public revenue and public expenditure and $S D$ is the saving deficit, symbolising the difference between private saving and private investment.

The relation (3) is derived from an accounting identity. Accordingly, left side of the equation explains the foreign deficit. Right side of the equation is composed of two deficits, the budget deficit and the private saving deficit.

Current account shows the size and the direction of international borrowing. When a country imports more than exports, there arises a current account deficit, which is financed by borrowing from abroad. Hence, a country with a current account deficit must be increasing its net foreign debt by the amount of deficit. To that end, a country with a current account deficit is importing present consumption and or investment (if investment goods are imported) and exporting future consumption and or investment spending.

Alternatively, the relationship between budget deficit and current account deficit can be further illustrated as follows.

According to the national account identity, national saving $(S)$ in an open economy is given by;

$$
S=Y-C-G-C A
$$

$$
\begin{aligned}
& \text { Alternatively, } \\
& S=I+C A \\
& \text { where, } \quad Y-C-G=I
\end{aligned}
$$

National savings can be divided into two components; private saving $(S p)$ and government saving $(S g)$ :

$$
S=S p+S g
$$


$S p$ is a part of personal disposable income $(Y d)$ that is saved rather than consumed. Hence,

$$
S p=Y d-C=(Y-T)-C
$$

$$
\begin{aligned}
& \text { Also, } \\
& S g=T-(G+R)=T-G-R
\end{aligned}
$$

Government savings $(\mathrm{Sg})$ is defined as the difference between government revenue collected in the form of taxes $(T)$ and expenditure in the form of purchases $(G)$ and transfers $(R)$. Accordingly, equation (8) in an identity form can be written as;

$$
S=S p+S g=(Y-T-C)+(T-G-R)=I+C A
$$

In order to analyse the effects of government saving decision in an open economy, the above identity can be written as,

$$
S p=I+C A-S g=I+C A-(T-G-R)
$$

And, alternatively, it can be said that;

$$
C A=S p-I-(G+R-T)
$$

where, $(G+R-T)$ is consolidated public sector deficit.

Based on the macroeconomic identity, two extreme cases are possible. If the difference between private saving and investment is stable over time, the fluctuations in the budget deficit will be fully translated to the current account and hence, the TDH will hold. The second case is REH, which assumes that the change in the budget deficit will be fully offset by change in saving.

Going forward, under the discussion on open economy macroeconomics linkages within a flexible exchange rate system, the relationship of interest rates and 
exchange rates in the budget deficit-current account deficit nexus can be explained as follows. The analysis is based on the loanable fund and Mundell-Fleming models (Salvatore, 2006).

Under the loanable funds model, large budget deficits put upward pressure on real interest rates and those high rates make such economy a relatively attractive place in which to invest and thus led to an inflow of foreign capital. In particular, high real interest rates stimulate private domestic savings, discourage private domestic investment, and encourage net capital inflows from abroad. While easing some of the strain on domestic credit markets and helping to finance the budget deficit, the foreign capital flows increases the value of domestic currency relative to the currencies of trading partners. This, in turn, affects the external competitiveness. In other words, the rise in the real exchange rate or real appreciation of the domestic currency results in a gradual increase in the current account deficit or net imports. ${ }^{3}$

Salvatore (2006) argues that Mundell-Fleming model can be used to analyse more explicitly the short-run dynamic relationship between budget and current account deficits for an open economy operating under a flexible exchange rate system. This analysis is based on the IS curve, which shows the various combinations of interest rates and national incomes at which the real goods market is in equilibrium, LM curve, which shows equilibrium in the money market and BP curve, which shows the various combinations of real interest rates and national incomes at which the nation's balance of payments is in equilibrium at a given exchange rate. Under this model, the larger budget deficit is associated with a larger capital inflow and a current account deficit than originally, establishing a direct link between the budget deficit and the current account deficit. Based on these arguments, it is evident that the dynamic progression from budget deficits to higher interest rates, to appreciation of the domestic currency and, finally, to current account deficits are based on sound theoretical analysis (Salvatore, 2006). This is in line with the Keynesian preposition, which leads to testable hypotheses of twin deficits. However, as mentioned in the introduction, counter views, for example, REH argues that there is no impact of budget deficits on current accounts. Based on the empirical context, these contending hypotheses are discussed in the following section.

3 However, although real interest rate is the key linkage between domestic activity and merchandise trade, the connection between interest rates and exchange rates remains controversial and subject to heterogenic empirical evidence (Abell, 1990). 


\section{Literature Review}

This section elaborates on relevant empirical literature, which contends to four testable hypotheses of twin deficits.

The first hypothesis is based on the Keynesian (or conventional) proposition and according to this view, an increase in budget deficit will cause a similar increase in current account deficit. However, due to the differences of countries and the developments of respective economies, the size of effects could be differing. A number of empirical studies support this view.

For example, Harko (2009) estimates the causal link between twin deficits and other macroeconomic variables by using multivariate time series data for Pakistan. The estimates of vector autoregressive (VAR) model demonstrate that causality link of deficits is flowing from budget deficit to prices to interest rate to capital flows to exchange rates and to trade deficit. Evidence also suggests that a reduction in the budget deficits might help to control the level of prices. Chowdhury and Saleh (2008) investigate the twin deficits relationship for Sri Lanka. Their empirical results support the Keynesian view to claim that there is a strong, positive link between the current account deficit, saving-investment balance and budget deficit during the period of 1970-2005. They find that a 1 per cent increase in the saving and investment gap will lead to 0.67 increases in current account deficit, while a 1 per cent increase in budget deficit will increase current account deficit by 0.20 per cent. Beetsma, Giuliodori and Klaassen (2008) explore the effects of public spending shocks for trade balances and budget balances in 14 European Union countries employing an annual panel VAR with exports and imports as separate variables. Their results are consistent with the TDH. Also, a split of their sample into relatively closed and opened economies shows that a public spending shock has a larger effect on output of the former group, while for the latter group, the trade balance exhibits a stronger deterioration. Salvatore (2006) finds strong empirical evidence on a direct relationship between the budget and current account deficits for United States, Japan, Germany, United Kingdom, France, Italy, and Canada. Saleh et al. (2005) examine the relationship between budget deficit and current account deficit in Sri Lanka, using the autoregressive distributed lag (ARDL) model and the bounds test for cointegration. They support the Keynesian view and find a strong linkage between the budget deficit and the current account deficit during the period 1970-2003. The empirical analysis shows that the direction of causality is uni-directional running from budget deficit to current account deficit. 
The second hypothesis refers to the REH. According to this view, an inter-temporal shift between taxes and budget deficits does not matter for the real interest rate, the quantity of investment or the current account balance. Using monthly data and the bounds testing approach to co-integration, Ratha (2009) finds that the twin-deficits theory holds for India in the short-run. However, it appears that there is no such relation in the longrun and hence, supports the REH. Therefore, it is concluded that the Keynesian view prevails in the short-run, and the neo-classical theory prevails in the long-run. Rahman and Mishra (2001) find that budget and current account deficits have no possibility of reverting to a long run equilibrium relationship in United States during the period 1946-1988. Kustepeli (2001) examines TDH in Turkey for the period 1975-1995 and suggests that there is no evidence for twin deficit relationship. Kaufmann, Scharler and Georg (1999) investigate the twin deficits relationship in Austria using quarterly data. Looking at the impulse responses of the current account to various shocks, they conclude that the reaction can be explained by a reallocation of expenditures over time due to changes in current and expected income and productivity as emphasised in the models in which REH holds. Enders and Lee (1990) investigate the REH for US economy using quarterly data and show some patterns in the recent US data, which appear to be inconsistent with the REH. Rigorous testing of the model, however, does not allow rejecting the independence of the federal government budget and current account deficits. In a study for G7 countries, Godley and Cripps (1983) also find no short run statistical relationship between the two deficits.

The third view is based on the unidirectional causality that runs from current account deficit to budget deficit. Based on this premise, Alkswani (2002) examines the relationship between twin deficits in the Saudi Arabian economy employing annual data and argues that in oil economy, neither the REH nor the Keynesian proposition is valid. The application of the error correction models (ECM) and Johansen co-integration confirms short and long-run relationships among the deficits, but Granger causality test asserts that trade deficit causes budget deficit. Alkswani argues that export revenue impacts government revenue, expenditure and the exports of goods and services and concludes that the two deficits are positively linked, but the direction of causality is from trade deficit to budget deficit. Bartlett (1999) investigates the secular relationship between the twin deficits in the United States and concludes that the relationship between the twin deficits is not consistent overtime. The evidence presented by Bartlett suggests that during the 1980s, the budget deficit and the current account deficit moved together. However, the direction of the relationship between two deficits has changed during the 1990s. Anoruo and Ramchander (1998) investigate the twin deficits relationship for five developing Southeast Asian economies (India, Indonesia, Korea, Malaysia and Philippines) and find trade deficits to cause budget deficits not vice versa. A study by 
Biswas, Tribedy and Saunders (1992) reveals a unidirectional causal relation running from structural budget deficits to net exports. However, their findings indicate a bi-directional causal relation between actual budget deficits and net exports. Using quarterly data for eight countries during the period of flexible exchange rates, Kearney and Monadjemi (1990) report that a temporary relationship between the two deficits may be indicated. They also find substantial evidence on reverse causation between the stance of fiscal policy and the current account balance.

The final set of evidence is based on the bi-directional causality between budget deficit and current account deficit. While budget deficit may cause current account deficit, the existence of significant feedback may cause causality between the two variables to run in both directions. Lau and Tang (2009) find that there is a bi-directional causality between budget deficit and current account deficit in Cambodia. Pahlavani and Saleh (2009) investigate the TDH for Philippines and Mukhtar, Zakaria and Ahmde (2007) for Pakistan. Both studies find that there is a bi-directional causality between budget deficit and current account deficit in both economies. Lau and Baharumshah (2006) argue that interest rates, exchange rates and budget deficit play an important role in explaining the current account balance. In a panel data investigation for a set of SEACEN countries, they find a two-way causal relationship between budget and current account deficit and that there exist two channels in which budget deficit affects the current account: directly budget deficits to current account deficits and indirectly via its impact on interest rates, exchange rate and current account deficits. Meanwhile, empirical results of a study by Islam (1998) suggest the presence of bilateral causality between trade deficits and budget deficits. Similarly, Darrat (1988) reports evidence to support the bi-directional causality between the twin deficits with additional variables of monetary base, real output, inflation, labour cost, exchange rate, short- and long-term interest rates and foreign real income. Darrat concludes that there is evidence for budget to trade deficit causality and a stronger evidence for trade to budget deficit causality in the US economy.

In addition to above, some empirical research provides mixed evidence. Grier and Ye (2009) investigate the relationship between the current account balance and government budget balance in the United States and conclude that there is no long-run relationship between the twin deficits. They also estimate a vector auto regression generalised auto regressive conditional heteroscedasticity (VAR-GARCH) $(1,1)$ model with demeaned current account balance and government budget balance, which allows examining their short-run connection in the presence of conditional heteroscedasticity. Based on both generalised impulse response functions as well as variance decompositions, they find a significantly positive and persistent short-run effect of budget shocks on the current account balance. Hashemzadeh and Wilson (2006) investigate the relationship 
between twin deficits for Egypt, Iran, Jordan, Kuwait, Syria and Turkey applying causality test and VAR models. Their findings suggest that the correlation between two deficits is complex and ambiguous and it is subject to change depending on the underlying tax system, trade patterns and barriers, the exchange rate, etc. Baharumshah et al. (2006) examine the TDH for Indonesia, Malaysia, the Philippines and Thailand and find that the Keynesian reasoning fits well for Thailand since a unidirectional relationship exists that runs from budget deficit to current account deficit. For Indonesia, the reverse causation (current account targeting) is detected while the empirical results indicate that a bi-directional pattern of causality exists for Malaysia and the Philippines. The results of the variance decompositions and impulse response functions suggest that the consequences of large budget and current account deficits become noticeable only overthe long-run. Fidrmuc (2002) examines the twin deficits relationship for a set of OECD, emerging and transition economies in Central and Eastern Europe and finds that the countries which pursue sustainable fiscal policies (e.g. Korea, Germany, Estonia, and the Czech Republic) display a high flexibility of the current account. This study shows that twin deficits emerged in the 1980s, however less evidence for twin deficits in the 1990s.Using Granger non-causality approach, Kouassi et al. (2002) find evidence for causality (either uni-directional or bi-directional) between twin deficits for some developing countries, but not for many developed countries. Kulkarni and Erickson (2001) investigate the twin deficits relationship in Mexico, India and Pakistan for the period of 1969 - 1997. In the case of Mexico, there is no evidence of twin deficit relationship and causality running in either direction. For India, there is strong evidence for twin deficits. They find that twin deficits exist in Pakistan, but causality runs in an exactly opposite direction. With three country cases showing different evidences, the TDH is not strongly supported. Khalid and Guan (1999) examine the long-term relationship and causality between budget deficit and current account deficit for five developed countries (United States, United Kingdom, France, Canada and Australia) and five developing countries (India, Indonesia, Pakistan, Egypt and Mexico). Their empirical results show that such secular relationship exists in four developing countries, while no developed country exhibits such a relationship. The results on the direction of causality are mixed for developing countries with evidence supporting that the current account deficits cause budget deficits for Indonesia and Pakistan while the reverse is true for Egypt and Mexico. The data does not support any causal relationship for the United Kingdom and Australia and some week evidence of bi-directional causality for Canada and India. In the context of the US, Miller and Russek (1989) find no long-run equilibrium relationship between the twin deficits despite the existence of some causal relationship. 


\section{Overview of the Developments in Twin Deficits in Sri Lanka}

During last five decades, the budget deficit continued to be quite high in Sri Lanka with an average of 8 per cent of GDP. Budget deficit in Sri Lanka peaked at 19.2 per cent of GDP in 1980, and continued to remain above 6 per cent during the subsequent period. Budget deficits and the accompanying current account deficits in 1960s resulted in a rapid depletion of external reserves causing serious foreign exchange problems, which lasted till the introduction of economic reforms in the late 1970s. However, since then, budget deficits continued to exert pressures on the external payments position. After economic reforms in 1977, government's involvement in heavy capital expenditure projects, such as Accelerated Mahaweli Development Programme, power generation and ports development projects impacted to increase the capital expenditure leading to expansions in budget deficits. After completion of these projects, budget deficit declined to around 7.9 per cent of GDP during 1990s (CBSL, 1998). Budget deficit has narrowed down commencing 2002 indicating a favourable trend towards the fiscal consolidation. However, it increased again in 2009 recording 9.9 per cent of GDP, reflecting a reversal of the declining trend. The significant shortfall in the government revenue, overrun in the recurrent expenditure and the increase in public investment over and above the expected level during the year were the main reasons for this increase (CBSL, 2009). However, it dropped again to 7.9 per cent in 2010 .

Table 1

Selected Macroeconomic Indicators of Sri Lanka (1960 - 2009)

Averages for Decades

\begin{tabular}{|l|c|c|c|c|c|}
\hline & $\begin{array}{c}1960- \\
1969\end{array}$ & $\begin{array}{c}1970- \\
1979\end{array}$ & $\begin{array}{c}1980- \\
1989\end{array}$ & $\begin{array}{c}1990- \\
1999\end{array}$ & $\begin{array}{c}2000- \\
2009\end{array}$ \\
\hline $\begin{array}{l}\text { Budget Balance (\% of GDP) } \\
\begin{array}{l}\text { Current Account Balance } \\
\quad \% \text { of GDP) }\end{array}\end{array}$ & -6.0 & -7.1 & -11.3 & -7.9 & -8.1 \\
$\begin{array}{l}\text { Interest Rate, 91-day } \\
\text { Treasury bill Rate (\%) }\end{array}$ & -2.8 & -2.0 & -7.7 & -4.8 & -3.5 \\
$\begin{array}{l}\text { Exchange Rate } \\
\quad \text { US dollar/Rupee) }\end{array}$ & 3.1 & 6.2 & 13.6 & 15.9 & 12.4 \\
$\begin{array}{l}\text { GDP Growth (\%) } \\
\begin{array}{l}\text { Inflation, based on Colombo } \\
\text { Consumers' Price Index (\%) }\end{array}\end{array}$ & 2.0 & 8.6 & 25.8 & 52.3 & 99.7 \\
\hline
\end{tabular}

Source : CBSL 
Sri Lankan economy has experienced current account deficits since 1960s and it peaked at 16.4 per cent of GDP in 1980. At the same time, current account surpluses were recorded only in 1965 and 1977 (0.7 per cent and 3.5 per cent of GDP, respectively).

During the 1960s and early 1970s, trade account was continuously in deficit as its exports which concentrated on only three primary agricultural exports and vulnerable to commodity price fluctuations were kept sufficient to meet its import requirement and heavy dependence on essential consumer imports. This coupled with the net outflows on services and transfers, led to continuous deficits in the current account (CBSL, 1998). The current account deficit widened during the open economy phase after 1977. During 1978 - 1985, current account deficit widened to 8.2 per cent of GDP reflecting the increased imports due to high demand with expanding economic activity and funded large infrastructure development projects and export processing zones. Hence, it is noteworthy that a part of the current account deficits in the post-liberalised period was also an outcome of the country's attempt to absorb foreign capital. However, with the expansion of exports and improvements in both the services and transfers accounts as well as completion of large donor funded development projects, the current account deficit declined significantly from high levels of the early 1980s and had remained at single digit levels since then. In recent years, increased worker remittances helped to contain the widening current account deficit and cushion the adverse impact of higher international commodity prices on the current account and exchange rates (CBSL, 2009). By end 2010, current account deficit remained at 2.9 per cent of GDP.

National savings stood at 12 per cent of GDP during 1960s and increased slightly in 1970s except 1974 and 1975. By 2009, national savings stood at 23.7 per cent of GDP.

\section{Data and Methodology}

\subsection{Data}

As already mentioned, this study attempts to explore the TDH for Sri Lanka using annual and quarterly data. We use annual data for the period 1960 to 2009, however quarterly data series only spans for the period 1990:Q1 to 2009:Q4 due to limited data availability. Data were obtained from annual reports and other various publications of the Central Bank of Sri Lanka (CBSL). [Due to the difficulty of obtaining a long series of data, quarterly budget deficit data used in this study was constructed using the treasury format 
(accounting classification) instead of economic classification, which is used by the CBSL for its analytical purposes]. ${ }^{4}$

Variables used in the empirical analysis, are defined in the following manner.

- $\mathrm{CA}=$ Current account deficit defined as net exports of goods and services plus net factor income

- $\mathrm{BD}=$ Budget deficit defined as the difference between government revenue and government expenditure

- EXR = Exchange rate expressed in terms of Sri Lankan rupees per US dollar

- $\mathrm{INR}=$ Interest rate represented by 91-days Treasury bill rate

Budget deficit and current account deficit are measured as a percentage of GDP and exchanges rate was in period average. ${ }^{5}$

Descriptive statistics of data are given in Table 2. It clearly indicates persistently high budget and current account deficits throughout the post-independent economic history of Sri Lanka.

Table 2

Descriptive Statistics

\begin{tabular}{|l|cccc|cccc|}
\hline & \multicolumn{3}{|c|}{ Annual Data (1960 - 2009) } & \multicolumn{3}{c|}{ Quarterly Data (1990:Q1 - 2009:Q4) } \\
\cline { 2 - 9 } & CA & BD & EXR & INR & CA & BD & EXR & INR \\
\hline Mean & -4.2 & -8.1 & 38.3 & 10.2 & -3.7 & -8.2 & 76.0 & 13.8 \\
Median & -3.5 & -7.2 & 26.3 & 10.0 & -3.7 & -8.2 & 72.3 & 13.2 \\
Maximum & 3.5 & -3.3 & 114.9 & 21.3 & 8.6 & 0.0 & 116.4 & 21.3 \\
Minimum & -16.4 & -19.2 & 4.8 & 2.6 & -14.7 & -18.2 & 40.0 & 7.0 \\
Std. Dev. & 3.4 & 2.8 & 36.0 & 5.7 & 3.9 & 3.1 & 26.0 & 3.9 \\
No. of observations & 50 & 50 & 50 & 50 & 80 & 80 & 80 & 80 \\
\hline
\end{tabular}

Prior to conducting the formal econometric analysis, we present the graphical presentation of two key variables in our analysis, i.e. budget deficit (BD) and current account balance (CA). Based on annual data, Figure 1 and 2 indicate that both BD and

4 Figures in the accounting classification (treasury format) are on gross basis while figures in the economic classification are on net basis. When calculating the budget deficit in according to the treasury format, total receipts of the government and total outlays (including debt repayments) are considered. However, according to the economic classification, only net receipt of the government is considered and debt repayments are not included in expenditure.

5 Salvatore (2006) suggests concentrating on the ratio of deficits to GDP, rather than on the absolute levels. 
CA exhibit a co-movement over the sample period. For example, in Figure 2, when budget deficit peaks in 1980, current account also follows the similar trend.

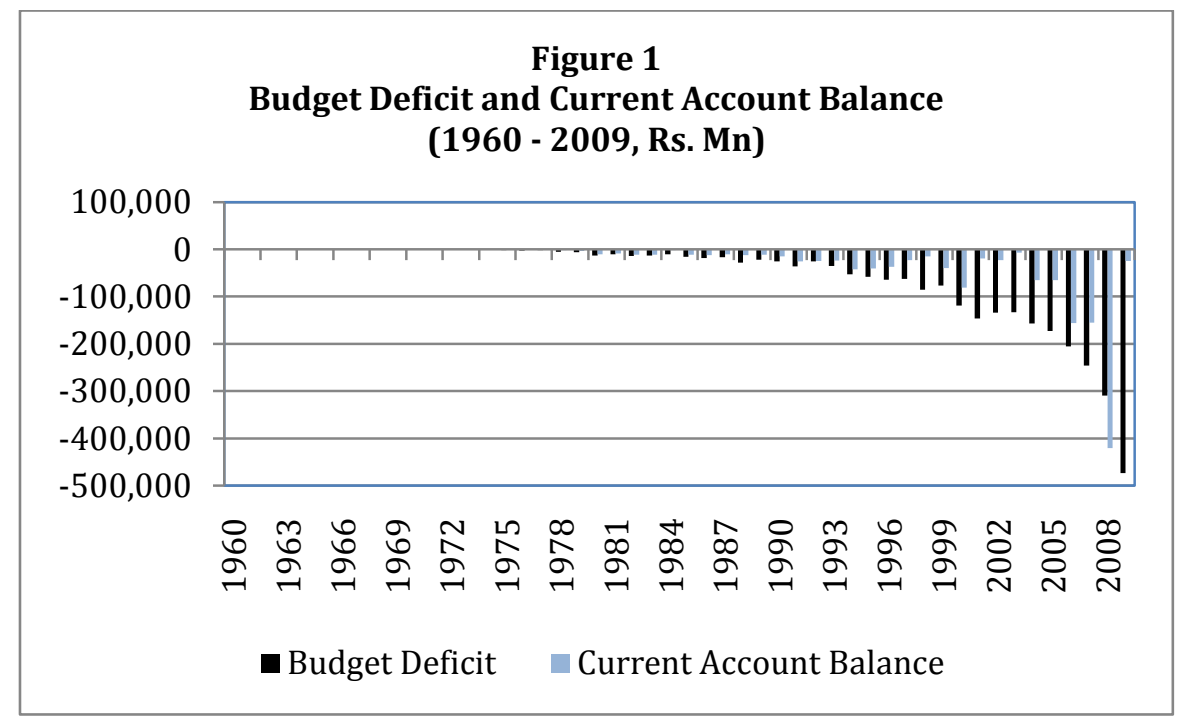

Source: CBSL

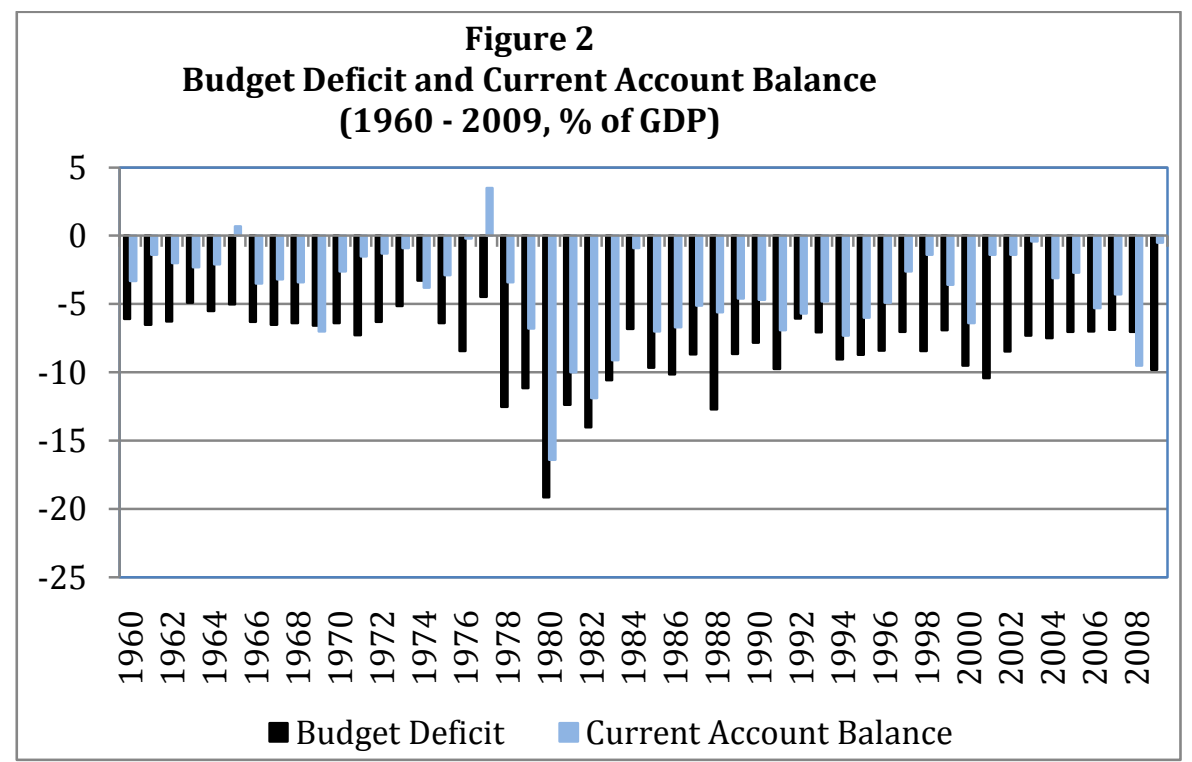

Source: CBSL 
Similarly, based on quarterly data, Figure 3 and 4 indicate that both $B D$ and $C A$ share a common trend indicating a possible long-run relationship between two deficits.

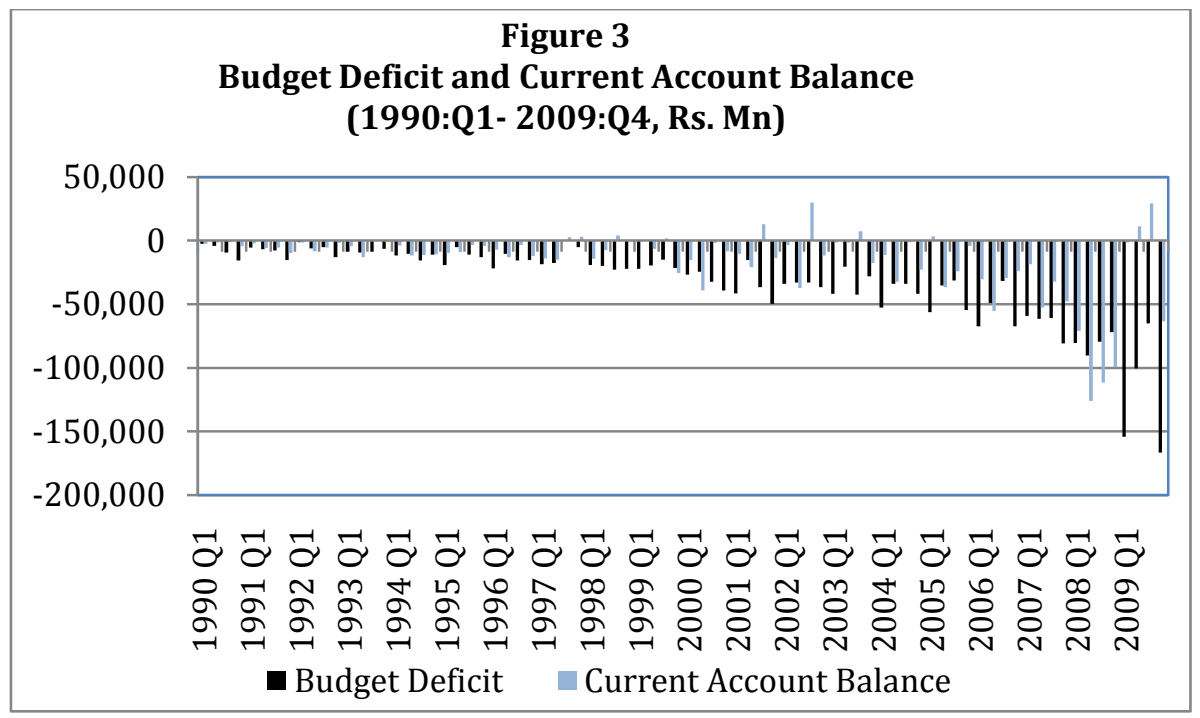

Source: CBSL

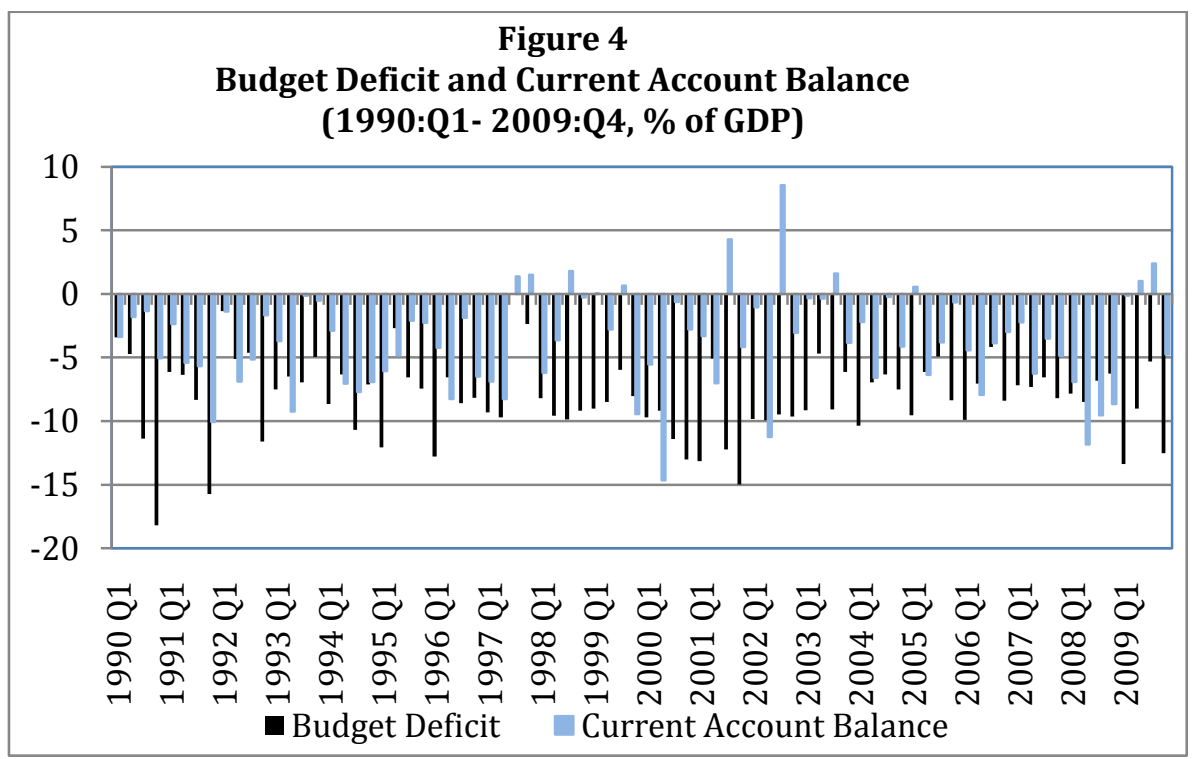

Source: CBSL 
In addition to these simple graphical illustrations, correlation analysis is often introduced either to support or against the relationship between budget and the current account balances (Salvatore, 2006).

Table 3 shows simple correlations between the current account and the budget account balances (both expressed as a percentage of GDP), un-lagged and lagged by $1-3$ years, as well as leading by $1-3$ years the current account.

Table 3

Correlation between Budget and Current Account Deficits

\begin{tabular}{|c|c|c|}
\hline Period & Annual Data & Quarterly Data \\
\hline$t-3$ & 0.70 & 0.06 \\
$t-2$ & 0.43 & -0.10 \\
$t-1$ & 0.29 & -0.04 \\
$t$ & 0.05 & 0.05 \\
$t+1$ & 0.48 & 0.04 \\
$t+2$ & 0.49 & -0.08 \\
$t+3$ & 0.35 & -0.11 \\
\hline
\end{tabular}

The correlations based on annual data in Table 3 strongly support the theory that budget balances are directly related to current account balances, i.e., budget deficits are positively related and lead current account deficits, and budget surpluses are associated with and lead current account surpluses. Although, the relationship is not strong for quarterly data, there still remains a positive correlation between budget deficits and current account deficits for the periods $t-3, t$ and $t+1$. Hence, the general conclusion that can be reached by these simple correlations is that the theory that budget deficits lead to current account deficits seem to hold.

In order to confirm or reject the TDH for Sri Lankan context, it is required to pursue a formal empirical investigation based on time series econometric techniques, which involve several diagnostic tests and modelling approaches. 


\subsection{Methodology}

By following the previous empirical literature (for example: Miller and Russek, 1989; Rahman and Mishra, 2001; Leachman and Francis, 2002; Baharumshah and Lau, 2007 and Harko, 2009 among others), we mainly employ the co-integration method to examine twin deficits in Sri Lanka. The main advantage of this test method is that it performs well even when the time series are non-stationary, and hence, in line with state of the art methodology. If a pair of time series is co-integrated, then there must be Granger causality at least one direction reflecting the direction of influence between two series (Granger, 1969 and 1981). Hence, in addition to co-integration analysis, by following Abell (1990); Normandin (1999); Hatemi-J and Shukur (2002); Mukhtar et al. (2007), etc., we employ Granger causality tests to further examine the direction of influence between budget deficits and current account deficits.

The following section briefly explains the methodology. ${ }^{6}$

\section{a. Testing for Stationarity}

The examination of stationarity property in a time series is closely related to testing for unit roots. Generally, most of the economic time series are non-stationary (mean and variance are not constants) and integrated. If a non-stationary time series $(X)$ needs to be differenced $(d)$ times until reaching stationarity, then the time series is said to be integrated of order $(d)$ denoted by $X_{t} \sim I(d)$. Hence, to avoid the problem of spurious regression and the failure to account for the appropriate dynamic specification, this study, first, performs unit roots tests on the variables. In this study, we use the Augmented Dickey - Fuller (ADF) to test for the stationary proeperty of the time series.

\section{b. Testing for Long Run Relationships}

The finding that the time series may contain a unit root guides us to use the non-stationary time series analysis. Engle and Granger (1987) pointed out that a linear combination of two or more non-stationary series may be stationary. If such a stationary linear combination exists, the non-stationary time series are said to be

6 Different econometric techniques used in this study are extensively used in contemporary empirical discourse. Hence, we do not intend to provide detailed mathematical explanations on such techniques in order to preserve space. However, required references are given as and when necessary for the benefit of researchers who would like to explore them extensively. 
co-integrated. The stationary linear combination is called the co-integrating equation and may be interpreted as a long-run equilibrium relationship among the variables. In summary, if two or more series are themselves non-stationary, but a linear combination of them is stationary, then the series are said to be co-integrated.

In this study, we use two approaches, i.e., residual based method and Johansen's method, which are widely used methods for modeling cointegrated relationships.

\section{i. Engle-Granger Co-integration}

The Engle-Granger (1987) residual-based tests for cointegration is simply unit root tests applied to the residuals obtained from static ordinary least squares (SOLS) estimation of the follwoing equation:

$$
Y_{t}=X_{t}^{\prime} \beta+D_{t}{ }^{\prime} \gamma_{1}+u_{1 t}
$$

Under the assumption that the series are not cointegrated, all linear combinations of ( $Y_{t}, X_{t}{ }^{\prime}$ ), including the residuals from SOLS, are unit root nonstationary. Therefore, a testof the null hypothesis of no cointegration against the alternative of cointegration corresponds to a unit root test of the null of nonstationarity against the alternative of stationarity. The Engle-Granger test uses a parametric, ADF approach. We consider the two standard ADF test statistics, one based on the t-statistic for testing the null hypothesis of nonstationarity $(\rho=1)$ and the other based directly on the normalised autocorrelation coefficient $(\hat{\rho}=1)$.

\section{ii. Johansen Method for Co-integration:}

The maximum likelihood procedure (Johansen's test), suggested by Johansen (1988 and 1991) and Johansen and Juselius (1990), is particularly preferable when the number of variables in the model exceeds two due to the possibility of existence of multiple co-integrating vectors.

To determine the number of co-intergrating vectors, Johansen (1988 and 1991) and Johansen and Juselius (1990) suggest two statistic tests. The first one is the trace test $\left(\lambda_{\text {trace }}\right)$. It tests the null hypothesis, which says that the number of distinct co-integrating vectors is less than or equal to $(q)$, against a general unrestricted alternative $(q=r)$. The trace statistic tests the null hypothesis of $r$ co-integrating relations against the alternative of $k$ cointegrating relations, where $k$ is the number of endogenous variables, for $r=0,1, \ldots k-1$. The alternative $k$ of cointegrating 
relations corresponds to the case where none of the series has a unit root and a stationary VAR maybe specified in terms of the levels of all of the series. This statistic is specified as follows:

$$
\lambda_{\text {trace }}(r)=-T \sum_{i=r+1}^{p} \ln \left(1-\lambda_{i}\right)
$$

where $\lambda_{\mathrm{r}+1} \ldots . \lambda_{\mathrm{n}}$ are the smallest value eigenvectors $(p-r)$.

The second statistical test is the maximal eigenvalue test $\left(\lambda_{\max }\right)$ that is calculated according the following formula:

$$
\lambda_{\max }(r, r+1)=-T \ln \left(1+\lambda_{r+1}\right)
$$

This concerns a test of the null hypothesis of $r$ cointegrating relations against the alternative of $r+1$ cointegrating relations.

\section{c. Testing for Directions of Causality:}

In the case of time series data, tests on the causality of variables and their directions have become important and meaningful exercises. Granger (1969) and Sims (1972) developed an operational framework of systematic testing and determination of causal direction. The approach is based on the axiom that the past and present may cause the future but the future cannot cause the past (Granger, 1980).

Accordingly, Granger causality test examines whether the contemporary movements of a variable $Y$ can be merely explained by the past values of $Y$, or adding lagged values of another variable $X$, that can improve the explanation of $Y$. Hence, $Y$ is said to be Granger-caused by $X$, if $X$ helps in predicting $Y$, or equivalently, if coefficients on lagged $X$ 's are statistically significant.

Granger causality between $X$ and $Y$ are said to be:

$$
\begin{aligned}
& Y_{t}=\sum_{i=1}^{n} \alpha_{i} X_{t-i}+\sum_{j=1}^{n} \beta_{j} Y_{t-j}+u_{1 t} \\
& X_{t}=\sum_{i=1}^{n} \lambda_{i} X_{t-i}+\sum_{j=1}^{n} \delta_{j} Y_{t-j}+u_{2 t}
\end{aligned}
$$


Where $u_{1 t}$ and $u_{2 t}$ are serially uncorrelated random disturbances with zero mean. If $X$ Granger causes $Y$;

$H_{0}: \alpha_{1}=\alpha_{2}=\alpha_{3}=\cdots \alpha_{m}=0$ is rejected against the alternative, $H_{1}$ : not $H_{0}$.

Similarly, If $Y$ Granger causes $X$;

$H_{0}^{*}: \delta_{1}=\delta_{2}=\delta_{3}=\cdots \delta_{m}=0$ is rejected against the alternative, $H_{1}^{*}$ : not $H_{0}^{*}$.

\section{Empirical Results and Discussion}

Prior to the empirical analysis, we examine stationary properties of both annual and quarterly data by conducting unit root tests.

Table 4 presents $t$ values obtained from ADF tests for both levels and first differences. The calculated $t$ values pertaining to levels are greater than 5 per cent critical value; hence do not reject the null hypothesis of non-stationarity. In other words, variables in the system are non-stationary. Results however prove that the hypotheses of unit roots can be rejected, when the variables are in first differences. In other words, since the $t$ values of first differenced data variables are less than 5 per cent critical value, we reject the null hypothesis of non-stationarity or say that variables in their first differences are stationary time series. Therefore, variables in the system for TDH are integrated of order (I).

Table 4

Augmented Dickey-Fuller Test on the Levels and First Differences of Variables (Annual and Quarterly Data)

\begin{tabular}{|c|c|c|c|c|c|}
\hline Variable & Level & First Difference & $\begin{array}{c}\text { Critical Values for } \\
\text { Rejection of Hypothesis of a } \\
\text { Unit Root at } 5 \%\end{array}$ & Decision & $\begin{array}{c}\text { Order of } \\
\text { Integration }\end{array}$ \\
\hline \multicolumn{6}{|l|}{ Annual Data } \\
\hline Current Account Deficit (CA) & -1.1997 & -5.4717 & -2.9238 & Stationary at First Difference & $\mathrm{I}(1)$ \\
\hline Budget Deficit (BD) & -2.3217 & -5.5812 & -2.9238 & Stationary at First Difference & $\mathrm{I}(1)$ \\
\hline Exchange Rate (EXR) & 2.8423 & -2.9845 & -2.9238 & Stationary at First Difference & $\mathrm{I}(1)$ \\
\hline Interest Rate (INR) & -2.2465 & -4.9264 & -2.9238 & Stationary at First Difference & $\mathrm{I}(1)$ \\
\hline \multicolumn{6}{|l|}{ Quarterly Data } \\
\hline Current Account Deficit (CA) & -0.2126 & -11.2712 & -2.8991 & Stationary at First Difference & $\mathrm{I}(1)$ \\
\hline Budget Deficit (BD) & -2.6125 & -10.1019 & -2.8991 & Stationary at First Difference & $\mathrm{I}(1)$ \\
\hline Exchange Rate (EXR) & -0.2083 & -5.6891 & -2.8991 & Stationary at First Difference & $\mathrm{I}(1)$ \\
\hline Interest Rate (INR) & -2.2413 & -6.0477 & -2.8991 & Stationary at First Difference & $\mathrm{I}(1)$ \\
\hline
\end{tabular}


The observation that variables have the same order of integratedness implies that variables move together overtime and hence, there exists a long-run relationship known as co-integration. Next, we test co-integration between variables, which would help to identify any equilibrium relationship between variables in the system. Based on the Engle-Granger method, results of regression equation and ADF test for residuals are summarised in Table 5 and 6, respectively, for both annual and quarterly data (estimate outputs obtained using the Eviews 7.0 software are given in Annexure 1).

\section{Table 5}

Engle-Granger Cointegration Test (Annual and Quarterly Data)

\begin{tabular}{|c|c|c|}
\hline Statistic & Value & Probability \\
\hline \multicolumn{3}{|l|}{ Annual Data } \\
\hline Engle-Granger tau-statistic & -5.892293 & 0.0033 \\
\hline Engle-Granger z-statistic & -41.83803 & 0.0021 \\
\hline \multicolumn{3}{|l|}{ Quarterly Data } \\
\hline Engle-Granger tau-statistic & -10.93685 & 0.0000 \\
\hline Engle-Granger z-statistic & -95.7525 & 0.0000 \\
\hline
\end{tabular}

Source: Model Estimates

As to the tests themselves, the Engle-Granger tau-statistic (t-statistic) and normalised autocorrelation coefficient (z-statistic) both reject the null hypothesis of no co-integration (unit root in the residuals) at the 5 per cent level. In addition, the tau-statistic rejects at a 5 per cent significance level. On balance, the evidence clearly suggests that variables in the system are co-integrated.

Table 6

ADF Test for Residuals (Annual and Quarterly Data)

\begin{tabular}{|l|l|l|l|l|}
\hline Variable & Coefficient & Std. Error & t-Statistic & Prob. \\
\hline Annual Data & -0.853837 & 0.144907 & -5.892293 & 0.00000 \\
\hline RESID(-1) & -1.212057 & 0.110823 & -10.93685 & 0.00000 \\
\hline Quarterly Data & RESID(-1) &
\end{tabular}

Source: Model Estimates

The bottom section of the output of the Engle-Granger test results depicts the results for the actual ADF test equation and are summarised in Table 6. It confirms that 
the residual of the system is stationary at levels that are integrated of order zero. This validates our proposition that variables in the system are co-integrated indicating long-run relationship between them.

Next, we test for long run co-movement of the variables in the system using the Johansen procedure. Tests results for the system based on annual data are summarised in Table 7 (Detailed model outputs for Johansen tests are given in Annex II).

Table 7

Johansen Cointegration Test (Annual Data: BD, CA, INR, EXR)

\begin{tabular}{|l|c|c|}
\hline \multicolumn{3}{|l|}{ Unrestricted Cointegration Rank Test (Trace) } \\
\hline $\begin{array}{l}\text { Hypothesized No. of Cointegrated } \\
\text { Equations }\end{array}$ & $\begin{array}{l}\text { Trace } \\
\text { Statistic }\end{array}$ & $\begin{array}{l}\text { Critical Value } \\
\text { (5\%) }\end{array}$ \\
\hline $\mathrm{r}=0$ & 52.99382 & 47.85613 \\
$\mathrm{r}<=1$ & 25.53198 & 29.79707 \\
$\mathrm{r}<=2$ & 10.28424 & 15.49471 \\
$\mathrm{r}<=3$ & 0.753067 & 3.841466 \\
\hline \multicolumn{3}{|l|}{ Unrestricted Cointegration Rank Test } \\
\hline Mypothesized No. of Cointegrated & Max-Eigen & Critical Value \\
Equations & 27.46183 & 27.58434 \\
\hline $\mathrm{r}=0$ & 15.24774 & 21.13162 \\
$\mathrm{r}<=1$ & 9.531174 & 14.26460 \\
$\mathrm{r}<=2$ & 0.753067 & 3.841466 \\
$\mathrm{r}<=3$ & \multicolumn{3}{|c|}{ Statistic } \\
\hline
\end{tabular}

Source: Model Estimates

The determination of the number of co-integrating vector is based on the use of two likelihood ratio $(L R)$ test statistics: the trace test and maximum eigenvalue test. As for Table 7, based on annual data for $B D, C A, I N R$ and $E X R$, trace test indicates 1 co-integrating equation at the 0.05 level. However, max eigenvalue test indicates no co-integration at the 0.05 level. This indicates that there is no significant long run co-movement between all four variables in the system. 
Given the possibility of interest rates and exchange rates having a significant impact for this outcome, we re-estimate the model only for $B D$ and $C A$, and summarised results are presented in Table $8 .^{7}$

Table 8

Johansen Cointegration Test (Annual Data: BD, CA)

\begin{tabular}{|c|c|c|}
\hline \multicolumn{3}{|l|}{ Unrestricted Cointegration Rank Test (Trace) } \\
\hline $\begin{array}{c}\text { Hypothesized No. of Cointegrated } \\
\text { Equations }\end{array}$ & $\begin{array}{c}\text { Trace } \\
\text { Statistic }\end{array}$ & $\begin{array}{c}\text { Critical Value } \\
(5 \%)\end{array}$ \\
\hline $\mathrm{r}=0$ & 24.95177 & 15.49471 \\
\hline $\mathrm{r}<=1$ & 6.045954 & 3.841466 \\
\hline \multicolumn{3}{|c|}{ Unrestricted Cointegration Rank Test (Maximum Eigenvalue) } \\
\hline $\begin{array}{l}\text { Hypothesized No. of Cointegrated } \\
\text { Equations }\end{array}$ & $\begin{array}{c}\text { Max-Eigen } \\
\text { Statistic }\end{array}$ & $\begin{array}{c}\text { Critical Value } \\
(5 \%)\end{array}$ \\
\hline $\mathrm{r}=0$ & 18.90581 & 14.26460 \\
\hline $\mathrm{r}<=1$ & 6.045954 & 3.841466 \\
\hline
\end{tabular}

Source: Model Estimates

According to Table 8, both trace statistic and max eigenvalue tests confirm that the system includes co-integrating equations since the hypothesis of no co-integrating vector $(r=0)$ is soundly rejected at 5 per cent level, however when including only budget deficit and current account balance. This indicates that financial variables, i.e., interest rates and exchange rates are not significant in explaining TDH for Sri Lanka when using annual data.

In order to affirm the existence of the $\mathrm{TDH}$, we estimate the model for quarterly data using the Johansen procedure. Tests results based on quarterly data are summarised in Table 9.

7 We examined co-integration between pairs of variables. Although a failed co-integration was detected for budget deficits and interest rates, significant co-integrating relationships were observed among other variables. 
Table 9

Johansen Cointegration Test (Quarterly Data: BD, CA, INR, EXR)

\begin{tabular}{|c|c|c|}
\hline \multicolumn{3}{|c|}{ Unrestricted Cointegration Rank Test (Trace) } \\
\hline $\begin{array}{c}\text { Hypothesized No. of } \\
\text { Cointegrated Equations }\end{array}$ & $\begin{array}{c}\text { Trace } \\
\text { Statistic }\end{array}$ & Critical Value (5\%) \\
\hline $\mathrm{r}=0$ & 95.08632 & 63.87610 \\
\hline $\mathrm{r}<=1$ & 49.98470 & 42.91525 \\
\hline $\mathrm{r}<=2$ & 11.72829 & 25.87211 \\
\hline $\mathrm{r}<=3$ & 4.123906 & 12.51798 \\
\hline \multicolumn{3}{|c|}{ Unrestricted Cointegration Rank Test (Maximum Eigenvalue) } \\
\hline $\begin{array}{c}\text { Hypothesized No. of } \\
\text { Cointegrated Equations }\end{array}$ & $\begin{array}{c}\text { Max-Eigen } \\
\text { Statistic }\end{array}$ & Critical Value $(5 \%)$ \\
\hline $\mathrm{r}=0$ & 45.10162 & 32.11832 \\
\hline $\mathrm{r}<=1$ & 38.25641 & 25.82321 \\
\hline $\mathrm{r}<=2$ & 7.604380 & 19.38704 \\
\hline $\mathrm{r}<=3$ & 4.123906 & 12.51798 \\
\hline
\end{tabular}

Source: Model Estimates

According to Table 9, both trace and max eigenvalue test statistics are higher than the critical value. Accordingly, the LR statistics confirm that all four variables in the system are co-integrated indicting long run co-movements between them supporting the prevalence of TDH for Sri Lanka. With compared to annual data, high frequency quarterly data, which captures dynamics in the economy, strongly suggest that there is a long-run relationship between budget and current account deficits. Also, simultaneous inclusion of both interest rate and exchange rate, i.e., financial variables confirm that they are significant variables in explaining TDH for Sri Lanka, however, with regard to quarterly data.

It is argued that transmission of twin deficits vary across exchange rate regimes (Leachman and Francis 2002). For example, Miller and Russek (1989) observe that twin deficits have no long-run relationship under flexible exchange rates. Similarly, Leachman and Francis (2002) find evidence to argue that in a floating exchange rate regime, neither of twin deficits is co-integrated or multi co-integrated. Therefore, although results are not reported, we estimated separate models using sub-sampled quarterly data for different regimes of exchanges rates (two samples for 1990-2001 and 2001-2009) in order to isolate the impact of exchange rate regimes on twin deficits. However, we detect 
significant co-integrating relationships between budget deficits and twin deficits irrespective the exchange rate system. ${ }^{8}$

Although cointegration methods confirm the existence of a long-run equilibrium relationship between budget deficit and current account deficit, such methods do not explain which of the two deficits cause the other. Granger causality test provides evidence to determine the direction of causality between the two deficits.

Table 10 presents results for hypotheses whether budget deficit Granger causes current account deficit, current account deficit Granger causes budget deficit, causality runs in both directions or both are independent (Detailed outputs are given in Annex III).

Table 10

Granger Causality Test (Annual and Quarterly Data)

\begin{tabular}{|c|c|c|c|}
\hline Null Hypothesis & F-Statistic & Probability & Decision \\
\hline \multicolumn{4}{|l|}{ Annual Data } \\
\hline No causality from budget deficits to current account deficits & 4.13706 & 0.02270 & Rejected \\
\hline No causality from current account deficits to budget deficits & 1.36973 & 0.26500 & Not Rejected \\
\hline \multicolumn{4}{|l|}{ Quarterly Data } \\
\hline No causality from budget deficits to current account deficits & 0.37879 & 0.03600 & Rejected \\
\hline No causality from current account deficits to budget deficits & 0.42041 & 0.65840 & Not Rejected \\
\hline
\end{tabular}

Source: Model Estimates

Granger causality results show that the hypothesis that budget deficit does not Granger cause current account deficit is rejected supporting the conventional hypothesis of $T D H$. Hence, results in Table 10 indicate that in the short run, budget deficit is causing the current account deficit. At the same time, we do not observe any reverse causation that can be used to support the Ricardian view. Moreover, based on annual data, we do not observe any causality running from budget deficits to interest rates, interest rates to exchange and exchange rates to current account deficits. However, Granger causality tests for quarterly data confirm that exchange rates have a significant unidirectional impact on current account deficits providing evidence for the channel of twin deficits and also strengthening the argument for holding the twin deficits in Sri Lanka.

8 Results for sub-sample analysis are available from the authors upon request. 
Overall, it is observed that there exists a long-run relationship between budget deficits and current account deficits and hence, such relationship confirms that current account balance in Sri Lanka is highly dependent on budget deficit. Hence, it can be concluded that $T D H$ holds for Sri Lanka.

\section{Conclusion}

Fiscal imbalances are frequently associated with economic disruptions, and hence, the discussion on fiscal issues deserves more attention. Given the specific importance of discussing the issues in regards to fiscal deficits, the purpose of this study is to examine twin deficits, particularly in the context of emerging country setting. As such, in this study, main objectives were to summarise theoretical arguments of twin deficits, review the existing literature, and examine the twin deficit phenomenon based on empirical evidence using data for Sri Lankan economy.

To achieve our objective, we estimate empirical models based on time series data for budget deficits, current account deficits, interest rates and exchange rates. The study also focuses investigating the direction of causality between the budget deficits and the current account deficits. Empirical analysis confirms that time series were integrated of order one and co-integrated indicating long-run equilibrium relationships between these two deficits. It also affirms the direction of causality running from budget deficits to current account deficits. This study also reveals that these deficits are co-integrated with key financial variables suggesting that there exists an underlying equilibrium relationship binding these key macroeconomic variables. In this context, our study supports the existence of twin deficit relationship in Sri Lanka. Hence, it is implied that budget cuts, or in other words, fiscal tightening, would tend to correct the current account deficits. As Khalid and Teo (1999) argue, many economists have argued that the way to reduce chronic current account deficits is to raise national saving by reducing the budget deficit and increasing the rate of private saving. The unidirectional causal relation running from the budget deficit to current account deficit suggests that there is a possibility of relying on curtailing budget deficits in an attempt to trim down current account deficits. To that end, one may argue that fiscal deficit may be treated as a fully controlled policy variable (Biswas et al., 1992).

On the policy front, these results draw several implications. First, as there exists a unidirectional impact from budget deficit to the current account balance, which causes pressures on the stability of exchange rates, Sri Lankan authorities would require 
pursuing policies towards fiscal consolidation in order to reduce high budget deficits on a sustainable basis. In particular, increasing budget deficits does not allow to exchange rate to depreciate to maintain the competitive power. To that end, as Abell (1990) argues, to reduce the pressure on current account deficits, authorities would need to reduce budget deficits on a sustainable basis. However, more caution needs to be examined in this regards. As Biswas et al. (1992) argue if productivity growth is not improved, cutting fiscal deficits to improve current account balance would tend to deteriorate current account balance due to the loss in competitive power and hence, aggravate the contractionary effect of a budget cut.

Being an emerging economy where the growth trajectory heavily depends on increased spending on capital investment while incurring essential recurrent expenditure, Sri Lanka would need to gear the fiscal discipline focusing to increase revenues. At the same time, it is also required to focus on external financing in accumulating Sri Lanka's capital stock. Second, it is also required to create conducive environment to attract foreign remittances and also foreign investment which would help to generate healthy external balances. As the stability in exchange rates are of paramount important to Sri Lanka, particularly in promoting the exports sector, minimising external imbalances through creating surpluses in current account is critical. Third, as a whole, Sri Lankan authorities would need to pursue policies for further reforms in external, fiscal and financial sectors, which would enable such sectors to perform without creating adverse imbalances.

We are aware that findings reported in the previous literature as well as empirical evidence in this study are not conclusive as the relationship between twin deficits is complex and ambiguous. Particularly, we emphasise that the relationships between the two deficits is subject to evolve depending on dynamics of the economy and due to the impact of various macroeconomic developments. To that end, use of alternative specifications and methods such as use of vector auto regressive models and impulse response functions (for example: Abell, 1990; Anoruo and Ramchandar, 1998), incorporating structural breaks (for example: Hatemi-J and Shukur, 2002; Baharumshah and Lau, 2007), estimating Granger non-causality tests (for example: Kouassi et al., 2004; Pahlavani and Saleh, 2009), multi-integration models (Leachman and Francis, 2002) and co-integration models with regime shifts (for example: Daly and Siddiki, 2009) would help to deepen our understanding of twin deficits and hence, to formulate appropriate macroeconomic policies in Sri Lanka. Such complex specifications as well as general equilibrium model based research is left for future discourse. 


\section{References}

Abell, J.D. (1990), "Twin Deficits during the 1980s: An Empirical investigation", Journal of Macroeconomics, winter 1990, 12 (1), 81-96.

Alkswani, M. A. (2002), "The Twin Deficits Phenomenon in Petroleum Economy: Evidence from Saudi Arabia", Discussion Papers of Department of Economics, King Saud University.

Anoruo, E. and Ramchander, S. (1998), "Current Account and Fiscal Deficits: Evidence from Five Developing Economies of Asia”, Journal of Asian Economics, 9 (3), 487 501.

Baharumshah, A. Z., Ismail, H. and Lau, E. (2009), "Twin Deficit Hypothesis and Capital Mobility: The ASEAN - 5 Perspective”, Jurnal Pengurusan.

Baharumshah, A. Z., Lau, E. and Khalid, A. M. (2006), "Testing Twin Deficits Hypothesis Using VARs and Variance Decomposition", Journal of the Asia Pacific economy, 11 (3),331-354.

Barro, R. J. (1974), “Are Government Bonds Net Wealth?”, Journal of Political Economy82 (6), 1095-1117.

Barro, R. J. (1989), “The Ricardian Approach to Budget Deficits”, Journal of EconomicPerspectives, 3 (2), 37-54.

Bartlett, B. (1999), "Are Budget Surpluses Equivalent to Tax Cuts? Idea House”, National Centre for Policy Analysis.

Beetsma, R., Giuliodori, M. and Klaassen, F. (2008), "The Effects of Public Spending Shocks on Trade Balances and Budget Deficits in the European Union", Journal of the European Economic Association, 6 (2-3), 414-423.

Belongia, M. T., and Stone, C. C. (1985), "Would Lower Federal Deficits Increase USFarm Exports?”, Federal Reserve Bank of St. Louis, Review, 5-19.

Biswas, B, Tribedy, G. and Saunders, P. (1992), "Further Analysis of the Twin Deficits", Contemporary Policy Issues, X, 104-107.

Blanchard, O. and Sheen, J. (2009), "Macroeconomics: Australian Edition", Pearson Australia.

Buchanan, J. M. (1976), "Barro on the Ricardian Equivalence Theorem", Journal ofPolitical Economy 84 (2), 337-342. 
Central Bank of Sri Lanka (1998), "Economic Progress of Independent Sri Lanka”, Colombo.

Central Bank of Sri Lanka, Annual Report, Various Issues, Colombo.

Chowdhury, K. and Saleh, A. S. (2008), "Testing the Keynesian Proposition of Twin Deficits in the Presence of Trade Liberalisation: Evidence from Sri Lanka”, Middle East Business and Economic Review, 18 (2), 1-13.

Colombage, S.S. (1991), “The Monetary Approach to Balance of Payments and Related Issues: Empirical Evidenceof Sri Lanka”, Staff Studies, Central Bank of Sri Lanka.

Daly, V. and Siddiki, J.U. (2009), "The Twin Deficits in OECD Countries: Cointegration Analysis with Regime Shifts”, Applied Economics Letters, 16, 1155-1164.

Darrat, A. F. (1988), “Have Large Deficits Caused Rising Trade Deficits?”, Southern Economic Journal, 54 (4), 879-887.

Enders, W. and Lee, B (1990), "Current Account and Budget Deficits: Twins or Distant Cousins?”, Review of Economics and Statistics, 72 (3), 373-381.

Engle, R. F. and Granger, C. W. J. (1987), "Co-integration and Error Correction: Representation, Estimation and Testing”, Econometrica, 55 (2), 251-276.

Edwards, S. (2001), “Does Current Account Matter?”, NBERWorking Papers, National Bureau of Economic Research, 8275.

Fleming, J.M. (1962), “Domestic Financial Policies Under Fixed and Under Floating Exchange Rates”, Staff Papers of International Monetary Fund, 10, 369-380.

Frankel, J. (2004), “Could Twin Deficits Jeopardise US Hegemony”, Journal of Policy Modelling, 28 (6), 653-663.

Godley, W. and Cripps, F. (1983), “Macroeconomics”, Oxford University Press.

Granger, C. W. J (1969), "Investigating Casual Relations by Econometric Models and Cross Spectral Methods”, Econometrica, 37 (3), 424-438.

Granger, C. W. J. (1981), "Some Properties of Time Series Data and Their Use in Econometric Model Specification”, Journal of Econometrica, 16, 121-130.

Grier, K. and Ye H. (2009), "Twin Sons of Different Mothers: The Long and the Short of the Twin Deficits Debate”, Economic Inquiry, 47 (6).

Harko, A. N. (2009), “Twin Deficits Causality Link - Evidence from Pakistan”, International Research Journal of Finance and Economics, 24, 54-70. 
Hashemzadeh, N. and Wilson, L. (2006), "The Dynamics of Current Account and Budget Deficits in Selected Countries of the Middle East and North Africa", International Research Journal of Finance and Economics, 5, 111-129.

Hatemi-J, A. and Shukur, G. (2002), “Multivariate-based Causality tests of Twin Deficits in the US”, Journal of Applied Statistics, 29 (6), 817-824.

Ibrahim, S. B. and Kumah, F.Y. (1996), "Co-movements in Budget Deficits, Money, Interest Rate, Exchange Rate and the Current Account Balance: Some EmpiricalEvidence”, Applied Economics, 28, 117-130.

Islam, M.F. (1998), “Brazil's Twin Deficits: An Empirical Examination”, Atlantic Economic Journal, 26 (2), 121-128.

Fidrmuc, J. (2002), "Twin Deficits: Implications of Current Account and Fiscal Imbalancesfor the Accession Countries”, In G. Tumpel-Gugurell and P. Mooslechner (Eds.), Structural Changes for Europe, 141-159.

Johansen, S. (1991), "Estimation and Hypothesis Testing of Cointegration Vectors in Gaussian Vector Autoregressive Models”, Econometrica, 59 (6), 1551 -1580.

Johansen, S. and Juselius, K. (1990), "Maximum Likelihood Estimation and Inference on Cointegration with Applications to the Demand for Money”, Oxford Bulletin of Economics and Statistics, 52, 169-210.

Johansen, S. (1988), "Statistical Analysis of Cointegration Vectors", Journal of Economic Dynamics and Control, 12 (2-3), 231-254.

Kaufmann, S., Scharler, J. and Georg, W. (1999), "The Austrian Current Account Deficit: Driven by Twin Deficits or by Intertemporal Expenditure Allocation?”, Working Papers of University of Vienna, 9903.

Kearney, C. and Monadjemi, M. (1990), "Fiscal Policy and Current Account Performance International Evidence on the Twin Deficits", Journal of Macroeconomics, 12(2), $172-218$.

Khalid, A. M. and Teo, G.W. (1999), "Causality Tests of Budget and Current AccountDeficits: Cross-Country Comparisons”, Empirical Economics, 24 (3), 389402 .

Kouassi, E., Mougoue', M. and Kymn, K.O. (2004), “Causality Tests of the Relationship between the Twin Deficits”, Empirical Economics, 29,503-525.

Kulkarni, K. G. and Erickson, E. L. (2001), “Twin Deficit Revisited: Evidence from India, Pakistan and Mexico”, Journal of Applied Business Research, 17 (2), 97-104. 
Kustepeli, Y.B. (2001), “An Empirical Investigation of the Feldstein Chain for Turkey”, Discussion Papers of Economics Department, Dokuz Eylul University.

Laney, L. (1984), "The Strong Dollar, the Current Account and Federal Deficits: Causeand Effect”, Federal Reserve Bank of Dallas Economic Review, 1, 1-14.

Lau, E. and Baharumshah, A. Z. (2006), "Twin Deficits Hypothesis in SEACEN Countries: A Panel Data Analysis of Relationships between Public Budget and Current Account Deficits", Applied Econometrics and International Development, 6 (2), 213-226.

Lau, E. and Tang, T. C. (2009), "Twin deficits in Cambodia: Are there Reasons for Concern? An Empirical Study", Discussion Papers of Monash University, Australia, $11(9)$.

Leachman, L.L. and Francis, B. (2002), “Twin Deficits: Apparition or Reality?”, Applied Economics, 34, 1121-1132.

Mann, C. L. (2002), "Perspectives on the U.S. Current Account Deficit and Sustainability”, Journal of Economic Perspectives, 16 (3), 131-152.

Miller, S. M. and Russek, F. S. (1989) “Are the Twin Deficits Really Related?”, Contemporary Policy Issues, 7 (4), 91-115.

Mundell, R.A. (1963), "Capital Mobility and Stabilization Policy Under Fixed and FlexibleExchange Rates", Canadian Journal of Economics and Political Science, 29 (4), 475-85.

Mukhtar, T., Zakaria, M. and Ahmed, M. (2007), “An empirical Investigation for the Twin Deficit Hypothesis in Pakistan”, Journal of Economic Cooperation, 28 (4), 63-80.

Normandin, M. (1999), “Budget Deficit Persistence and the Twin Deficits Hypothesis”, Journal of International Economics, 49 (1), 171-193.

Pahlavani, M. and Saleh, A. S. (2009), "Budget Deficits and Current Account Deficits in the Philippines: A Casual Relationship?”, American Journal of Applied Sciences, $6(8), 1515-1520$.

Rahman, M. and Mishra, B. (2001), "Cointegration of U.S. Budget and Current Account Deficits: Twins or Strangers?”, Journal of Economics and Finance, 16(2), 119-127.

Ratha, A. (2007), “Twin Deficits or Distant Cousins? Evidence from India”, Working Papers of Department of Economics, St. Cloud State University, USA. 
Saleh, A. S., Nair, M. and Agalewatte, T. (2005), "The Twin Deficits Problem in Sri Lanka: An Econometric Analysis”, South Asia Economic Journal, 6 (2), 221-239.

Salvatore, D. (2006), "Twin Deficits in the G-7 Countries and Global Structural Imbalances”, Journal of Policy Modeling, 28 (6), 701-712.

Taylor, A. M. (2002), “A Century of Current Account Dynamics”, NBER Working Papers, National Bureau of Economic Research, 8927.

Sims, C. (1972): “Money, Income and Causality,” American Economic Review, 62 (4), 540-552.

Sims, C. (1980), “Macroeconomics and Reality”, Econometrica, 48 (1), 1-48.

Sims, C. (1980a), “Comparison of Inter-War and Post war Business Cycles”, American Economic Review, 70, 250-257. 


\section{Annex I: Engle Granger Cointegration Tests}

\section{Annual Data}

Cointegration Test - Engle-Granger

Date: 02/20/11 Time: 15:46

Equation: EQ01

Specification: CA BD INR EXR C @TREND

Cointegrating equation deterministics: C @TREND

Null hypothesis: Series are not cointegrated

Automatic lag specification (lag=0 based on Schwarz Info Criterion, maxlag=10)

\begin{tabular}{lll}
\hline \hline & Value & Prob.* $^{*}$ \\
\hline Engle-Granger tau-statistic & -5.892293 & 0.0033 \\
Engle-Granger z-statistic & -41.83803 & 0.0021 \\
\hline \hline
\end{tabular}

*MacKinnon (1996) p-values.

Intermediate Results:

\begin{tabular}{lc}
\hline Rho - 1 & -0.853837 \\
Rho S.E. & 0.144907 \\
Residual variance & 5.000960 \\
Long-run residual variance & 5.000960 \\
Number of lags & 0 \\
Number of observations & 49 \\
Number of stochastic trends** & 4
\end{tabular}

${ }^{* *}$ Number of stochastic trends in asymptotic distribution.

Engle-Granger Test Equation:

Dependent Variable: D(RESID)

Method: Least Squares

Date: 02/20/11 Time: 15:46

Sample (adjusted): 19612009

Included observations: 49 after adjustments

\begin{tabular}{lrlrr}
\hline \hline \multicolumn{1}{c}{ Variable } & Coefficient & \multicolumn{1}{c}{ Std. Error } & t-Statistic & Prob. \\
\hline \hline \multicolumn{1}{c}{ RESID(-1) } & -0.853837 & 0.144907 & -5.892293 & 0.0000 \\
\hline \hline R-squared & 0.419452 & Mean dependent var & 0.062805 \\
Adjusted R-squared & 0.419452 & S.D. dependent var & 2.934996 \\
S.E. of regression & 2.236283 & Akaike info criterion & 4.467704 \\
Sum squared resid & 240.0461 & Schwarz criterion & 4.506313 \\
Log likelihood & -108.4587 & Hannan-Quinn criter. & 4.482352 \\
Durbin-Watson stat & 1.909815 & & \\
\hline
\end{tabular}




\section{Quarterly Data}

Cointegration Test - Engle-Granger

Date: 02/20/11 Time: 17:03

Equation: EQ02

Specification: CA_Q BD_Q INR_Q EXR_Q C @TREND

Cointegrating equation deterministics: C @TREND

Null hypothesis: Series are not cointegrated

Automatic lag specification (lag=0 based on Schwarz Info Criterion, maxlag=11)

\begin{tabular}{lcl}
\hline \hline & Value & Prob.* \\
\hline Engle-Granger tau-statistic & -10.93685 & 0.0000 \\
Engle-Granger z-statistic & -95.75250 & 0.0000 \\
\hline \hline
\end{tabular}

*MacKinnon (1996) p-values.

Intermediate Results:

\begin{tabular}{lc}
\hline Rho -1 & -1.212057 \\
Rho S.E. & 0.110823 \\
Residual variance & 30.11791 \\
Long-run residual variance & 30.11791 \\
Number of lags & 0 \\
Number of observations & 79 \\
Number of stochastic trends** & 4 \\
\hline \hline
\end{tabular}

**Number of stochastic trends in asymptotic distribution.

Engle-Granger Test Equation:

Dependent Variable: D(RESID)

Method: Least Squares

Date: 02/20/11 Time: 17:03

Sample (adjusted): 1990Q2 2009Q4

Included observations: 79 after adjustments

\begin{tabular}{lrlrr}
\hline \hline \multicolumn{1}{c}{ Variable } & Coefficient & Std. Error & t-Statistic & Prob. \\
\hline \hline \multicolumn{1}{c}{ RESID(-1) } & -1.212057 & 0.110823 & -10.93685 & 0.0000 \\
\hline \hline R-squared & 0.605282 & Mean dependent var & -0.045256 \\
Adjusted R-squared & 0.605282 & S.D. dependent var & 8.735118 \\
S.E. of regression & 5.487979 & Akaike info criterion & 6.255575 \\
Sum squared resid & 2349.197 & Schwarz criterion & 6.285568 \\
Log likelihood & -246.0952 & Hannan-Quinn criter. & 6.267591 \\
Durbin-Watson stat & 2.056695 & & \\
\hline \hline
\end{tabular}




\section{Annex II: Johansen Cointegration Tests}

\section{Annual Data: Budget Deficit, Current Account Balance, Interest \\ Rate and Exchange Rate}

Date: 02/20/11 Time: 16:19

Sample (adjusted): 19622009

Included observations: 48 after adjustments

Trend assumption: Linear deterministic trend

Series: CA BD INR EXR

Lags interval (in first differences): 1 to 1

Unrestricted Cointegration Rank Test (Trace)

\begin{tabular}{ccccc}
\hline \hline $\begin{array}{c}\text { Hypothesized } \\
\text { No. of CE(s) }\end{array}$ & Eigenvalue & $\begin{array}{c}\text { Trace } \\
\text { Statistic }\end{array}$ & $\begin{array}{c}0.05 \\
\text { Critical Value }\end{array}$ & Prob.** $^{*}$ \\
\hline \hline None ${ }^{*}$ & 0.435673 & 52.99382 & 47.85613 & 0.0152 \\
At most 1 & 0.272151 & 25.53198 & 29.79707 & 0.1433 \\
At most 2 & 0.180094 & 10.28424 & 15.49471 & 0.2595 \\
At most 3 & 0.015566 & 0.753067 & 3.841466 & 0.3855 \\
\hline \hline
\end{tabular}

Trace test indicates 1 cointegrating eqn(s) at the 0.05 level

* denotes rejection of the hypothesis at the 0.05 level

**MacKinnon-Haug-Michelis (1999) p-values

Unrestricted Cointegration Rank Test (Maximum Eigenvalue)

\begin{tabular}{ccccc}
\hline \hline $\begin{array}{c}\text { Hypothesized } \\
\text { No. of CE(s) }\end{array}$ & Eigenvalue & $\begin{array}{c}\text { Max-Eigen } \\
\text { Statistic }\end{array}$ & $\begin{array}{c}0.05 \\
\text { Critical Value }\end{array}$ & Prob.** $^{* *}$ \\
\hline \hline None & 0.435673 & 27.46183 & 27.58434 & 0.0518 \\
At most 1 & 0.272151 & 15.24774 & 21.13162 & 0.2719 \\
At most 2 & 0.180094 & 9.531174 & 14.26460 & 0.2446 \\
At most 3 & 0.015566 & 0.753067 & 3.841466 & 0.3855 \\
\hline \hline
\end{tabular}

Max-eigenvalue test indicates no cointegration at the 0.05 level

* denotes rejection of the hypothesis at the 0.05 level

**MacKinnon-Haug-Michelis (1999) p-values 
Unrestricted Cointegrating Coefficients (normalized by b'*S11*b=I):

\begin{tabular}{cccc}
\hline \hline CA & BD & INR & EXR \\
-0.628444 & 0.520852 & -0.112119 & 0.001163 \\
-0.016876 & -0.004876 & -0.169473 & -0.013955 \\
0.019784 & 0.472302 & 0.145281 & -0.017453 \\
0.067575 & -0.113818 & 0.164980 & -0.034622 \\
\hline \hline
\end{tabular}

Unrestricted Adjustment Coefficients (alpha):

\begin{tabular}{crrrr}
\hline \hline $\mathrm{D}(\mathrm{CA})$ & 1.717564 & -0.780717 & -0.458259 & -0.005200 \\
$\mathrm{D}(\mathrm{BD})$ & 0.472634 & -0.055740 & -0.794445 & 0.132384 \\
$\mathrm{D}(\mathrm{INR})$ & -0.219085 & 0.997144 & -0.491044 & -0.252216 \\
$\mathrm{D}(\mathrm{EXR})$ & -0.275657 & -1.162204 & -0.127891 & -0.161811 \\
\hline \hline
\end{tabular}

1 Cointegrating Equation(s): $\quad$ Log likelihood $\quad-436.1457$

Normalized cointegrating coefficients (standard error in parentheses)

$\begin{array}{cccc}\text { CA } & \text { BD } & \text { INR } & \text { EXR } \\ 1.000000 & -0.828796 & 0.178407 & -0.001850 \\ & (0.13759) & (0.07423) & (0.01143)\end{array}$

Adjustment coefficients (standard error in parentheses)

$\begin{array}{ll}\mathrm{D}(\mathrm{CA}) & -1.079392 \\ & (0.26072) \\ \mathrm{D}(\mathrm{BD}) & -0.297024 \\ & (0.21534) \\ \mathrm{D}(\mathrm{INR}) & 0.137682 \\ & (0.29318) \\ \mathrm{D}(\mathrm{EXR}) & 0.173235 \\ & (0.25351)\end{array}$

2 Cointegrating Equation(s): $\quad$ Log likelihood $\quad-428.5218$

Normalized cointegrating coefficients (standard error in parentheses)

\begin{tabular}{cccc} 
CA & BD & INR & EXR \\
1.000000 & 0.000000 & 7.492411 & 0.612692 \\
& & $(2.57677)$ & $(0.43153)$ \\
0.000000 & \multirow{2}{*}{1.000000} & 8.824850 & 0.741488 \\
& & $(3.10953)$ & $(0.52075)$
\end{tabular}




\begin{tabular}{ccc} 
Adjustment coefficients (standard error in parentheses) \\
D(CA) & -1.066216 & 0.898403 \\
& $(0.24957)$ & $(0.20678)$ \\
D(BD) & -0.296083 & 0.246444 \\
& $(0.21535)$ & $(0.17842)$ \\
D(INR) & 0.120854 & -0.118973 \\
& $(0.27688)$ & $(0.22940)$ \\
D(EXR) & 0.192849 & -0.137910 \\
& $(0.22716)$ & $(0.18821)$ \\
\hline \hline
\end{tabular}

3 Cointegrating Equation(s): $\quad$ Log likelihood $\quad-423.7562$

$\begin{array}{cccc}\text { Normalized cointegrating coefficients (standard error in parentheses) } \\ \text { CA } & \text { BD } & \text { INR } & \text { EXR } \\ 1.000000 & 0.000000 & 0.000000 & -0.069521 \\ & & & (0.03295) \\ 0.000000 & 1.000000 & 0.000000 & -0.062049 \\ & & & 0.02955) \\ 0.000000 & 0.000000 & 1.000000 & 0.091054 \\ & & & 0.05576)\end{array}$

Adjustment coefficients (standard error in parentheses)

$\begin{array}{lccc}\text { D(CA) } & -1.075283 & 0.681966 & -0.126837 \\ & (0.24570) & (0.27467) & (0.09758) \\ \text { D(BD) } & -0.311800 & -0.128775 & -0.158963 \\ & (0.20118) & (0.22490) & (0.07990) \\ \text { D(INR) } & 0.111139 & -0.350894 & -0.215765 \\ & (0.27289) & (0.30505) & (0.10838) \\ \text { D(EXR) } & 0.190318 & -0.198313 & 0.209288 \\ & (0.22693) & (0.25368) & (0.09013)\end{array}$




\section{Annual Data: Budget Deficit and Current Account Balance (excluding interest rate and exchange rates)}

Date: 02/20/11 Time: $16: 18$

Sample (adjusted): 19622009

Included observations: 48 after adjustments

Trend assumption: Linear deterministic trend

Series: CA BD

Lags interval (in first differences): 1 to 1

Unrestricted Cointegration Rank Test (Trace)

\begin{tabular}{ccccc}
\hline \hline $\begin{array}{c}\text { Hypothesized } \\
\text { No. of CE(s) }\end{array}$ & Eigenvalue & $\begin{array}{c}\text { Trace } \\
\text { Statistic }\end{array}$ & $\begin{array}{c}0.05 \\
\text { Critical Value }\end{array}$ & Prob.** $^{* *}$ \\
\hline \hline None & 0.325559 & 24.95177 & 15.49471 & 0.0014 \\
At most $1 *$ & 0.118348 & 6.045954 & 3.841466 & 0.0139 \\
\hline \hline
\end{tabular}

Trace test indicates 2 cointegrating eqn(s) at the 0.05 level

* denotes rejection of the hypothesis at the 0.05 level

**MacKinnon-Haug-Michelis (1999) p-values

Unrestricted Cointegration Rank Test (Maximum Eigenvalue)

\begin{tabular}{ccccc}
\hline \hline $\begin{array}{c}\text { Hypothesized } \\
\text { No. of CE(s) }\end{array}$ & Eigenvalue & $\begin{array}{c}\text { Max-Eigen } \\
\text { Statistic }\end{array}$ & $\begin{array}{c}0.05 \\
\text { Critical Value }\end{array}$ & Prob.** \\
\hline \hline None ${ }^{*}$ & 0.325559 & 18.90581 & 14.26460 & 0.0086 \\
At most $1 *$ & 0.118348 & 6.045954 & 3.841466 & 0.0139 \\
\hline \hline
\end{tabular}

Max-eigenvalue test indicates 2 cointegrating eqn(s) at the 0.05 level

* denotes rejection of the hypothesis at the 0.05 level

**MacKinnon-Haug-Michelis (1999) p-values

Unrestricted Cointegrating Coefficients (normalized by b'*S11*b=I):

\begin{tabular}{cc}
\hline \hline CA & BD \\
-0.531195 & 0.474040 \\
-0.032419 & 0.441781 \\
\hline \hline
\end{tabular}


Unrestricted Adjustment Coefficients (alpha):

\begin{tabular}{|c|c|c|c|}
\hline $\begin{array}{l}\mathrm{D}(\mathrm{CA}) \\
\mathrm{D}(\mathrm{BD})\end{array}$ & $\begin{array}{l}1.806563 \\
0.331139\end{array}$ & $\begin{array}{l}-0.338051 \\
-0.759969\end{array}$ & \\
\hline \multicolumn{2}{|c|}{1 Cointegrating Equation(s): } & Log likelihood & -216.0484 \\
\hline \multicolumn{4}{|c|}{ Normalized cointegrating coefficients (standard error in parentheses) } \\
\hline $\mathrm{CA}$ & $\mathrm{BD}$ & & \\
\hline 1.000000 & $\begin{array}{r}-0.892404 \\
(0.16833)\end{array}$ & & \\
\hline \multicolumn{4}{|c|}{ Adjustment coefficients (standard error in parentheses) } \\
\hline $\mathrm{D}(\mathrm{CA})$ & $\begin{array}{r}-0.959637 \\
(0.22260)\end{array}$ & & \\
\hline $\mathrm{D}(\mathrm{BD})$ & $\begin{array}{r}-0.175899 \\
(0.18098)\end{array}$ & & \\
\hline
\end{tabular}

\section{Quarterly Data: Budget Deficit, Current Account Balance, Interest \\ Rate and Exchange Rate}

Date: 02/20/11 Time: 17:04

Sample (adjusted): 1990Q4 2009Q4

Included observations: 77 after adjustments

Trend assumption: Linear deterministic trend (restricted)

Series: CA_Q BD_Q INR_Q EXR_Q

Lags interval (in first differences): 1 to 2

Unrestricted Cointegration Rank Test (Trace)

\begin{tabular}{ccccc}
\hline \hline $\begin{array}{c}\text { Hypothesized } \\
\text { No. of CE(s) }\end{array}$ & Eigenvalue & $\begin{array}{c}\text { Trace } \\
\text { Statistic }\end{array}$ & $\begin{array}{c}0.05 \\
\text { Critical Value }\end{array}$ & Prob.** \\
\hline \hline None ${ }^{*}$ & 0.443304 & 95.08632 & 63.87610 & 0.0000 \\
At most $1 *$ & 0.391548 & 49.98470 & 42.91525 & 0.0085 \\
At most 2 & 0.094038 & 11.72829 & 25.87211 & 0.8304 \\
At most 3 & 0.052148 & 4.123906 & 12.51798 & 0.7241 \\
\hline \hline
\end{tabular}

Trace test indicates 2 cointegrating eqn(s) at the 0.05 level

* denotes rejection of the hypothesis at the 0.05 level

**MacKinnon-Haug-Michelis (1999) p-values 
Unrestricted Cointegration Rank Test (Maximum Eigenvalue)

\begin{tabular}{|c|c|c|c|c|}
\hline $\begin{array}{l}\text { Hypothesized } \\
\text { No. of CE(s) }\end{array}$ & Eigenvalue & $\begin{array}{l}\text { Max-Eigen } \\
\text { Statistic }\end{array}$ & $\begin{array}{c}0.05 \\
\text { Critical Value }\end{array}$ & Prob.** \\
\hline None $*$ & 0.443304 & 45.10162 & 32.11832 & 0.0008 \\
\hline At most $1^{*}$ & 0.391548 & 38.25641 & 25.82321 & 0.0007 \\
\hline At most 2 & 0.094038 & 7.604380 & 19.38704 & 0.8554 \\
\hline At most 3 & 0.052148 & 4.123906 & 12.51798 & 0.7241 \\
\hline
\end{tabular}

Max-eigenvalue test indicates 2 cointegrating eqn(s) at the 0.05 level

$*$ denotes rejection of the hypothesis at the 0.05 level

**MacKinnon-Haug-Michelis (1999) p-values

Unrestricted Cointegrating Coefficients (normalized by b'*S11*b=I):

\begin{tabular}{ccccc}
\hline \hline CA_Q & BD_Q & INR_Q & EXR_Q & @TREND(90Q2) \\
-0.265828 & -0.458955 & -0.035978 & -0.045150 & 0.062067 \\
-0.309462 & 0.451756 & 0.078743 & 0.088224 & -0.077713 \\
0.002534 & 0.055198 & -0.301769 & -0.081916 & 0.070062 \\
0.022726 & 0.013489 & -0.077448 & 0.215907 & -0.253031 \\
\hline \hline
\end{tabular}

Unrestricted Adjustment Coefficients (alpha):

\begin{tabular}{rrrrr}
\hline \hline D(CA_Q) & 2.749607 & 3.006112 & -0.446280 & -0.263968 \\
D(BD_Q) & 1.812144 & -1.055679 & -0.087413 & 0.306680 \\
D(INR_Q) & 0.360915 & -0.004453 & 0.579561 & 0.091358 \\
D(EXR_Q) & 0.135543 & -0.326072 & 0.101399 & -0.276368 \\
\hline \hline 1 Cointegrating Equation(s): & Log likelihood & -730.7884 & \\
\hline \hline
\end{tabular}

Normalized cointegrating coefficients (standard error in parentheses)

$\begin{array}{ccccc}\text { CA_Q } & \text { BD_Q } & \text { INR_Q } & \text { EXR_Q } & \text { @TREND(90Q2) } \\ 1.000000 & 1.726513 & 0.135343 & 0.169847 & -0.233487 \\ & (0.33225) & (0.16517) & (0.12945) & (0.14477)\end{array}$

Adjustment coefficients (standard error in parentheses)

$\begin{array}{lr}\text { D(CA_Q) } & -0.730922 \\ & (0.19493) \\ \text { D(BD_Q) } & -0.481718 \\ & (0.09664) \\ \text { D(INR_Q }) & -0.095941 \\ & (0.06410) \\ \text { D(EXR_Q) } & -0.036031 \\ & (0.04439)\end{array}$


2 Cointegrating Equation(s):

Log likelihood

$-711.6602$

Normalized cointegrating coefficients (standard error in parentheses)

\begin{tabular}{ccccc} 
CA_Q & BD_Q & INR_Q & EXR_Q & @TREND(90Q2) \\
1.000000 & 0.000000 & -0.075868 & -0.076661 & 0.029100 \\
& & $(0.11276)$ & $(0.08364)$ & $(0.09385)$ \\
0.000000 & \multirow{2}{*}{1.000000} & 0.122334 & 0.142778 & -0.152091 \\
& & $(0.07080)$ & $(0.05252)$ & $(0.05893)$
\end{tabular}

Adjustment coefficients (standard error in parentheses)

$\begin{array}{lrr}\text { D(CA_Q) } & -1.661199 & 0.096082 \\ & (0.25893) & (0.40874) \\ \text { D(BD_Q) } & -0.155025 & -1.308602 \\ & (0.13866) & (0.21889) \\ \text { D(INR_Q) } & -0.094563 & -0.167655 \\ & (0.09837) & (0.15528) \\ \text { D(EXR_Q) } & 0.064876 & -0.209513 \\ & (0.06616) & (0.10444)\end{array}$

3 Cointegrating Equation(s): $\quad$ Log likelihood $\quad-707.8580$

\begin{tabular}{ccccc} 
Normalized cointegrating coefficients (standard error in parentheses) & \\
CA_Q & BD_Q & INR_Q & EXR_Q & @TREND(90Q2) \\
1.000000 & 0.000000 & 0.000000 & -0.054613 & 0.009813 \\
& & & $(0.08559)$ & $(0.09688)$ \\
0.000000 & 1.000000 & 0.000000 & 0.107227 & -0.120991 \\
& & & $(0.06170)$ & $(0.06984)$ \\
0.000000 & 0.000000 & \multirow{2}{*}{1.000000} & 0.290608 & -0.254219 \\
& & & $(0.28605)$ & $(0.32377)$
\end{tabular}

Adjustment coefficients (standard error in parentheses)

$\begin{array}{lrrr}\text { D(CA_Q) } & -1.662330 & 0.071448 & 0.272460 \\ & (0.25798) & (0.40873) & (0.19852) \\ \text { D(BD_Q) } & -0.155247 & -1.313427 & -0.121946 \\ & (0.13860) & (0.21958) & (0.10666) \\ \text { D(INR_Q) } & -0.093094 & -0.135664 & -0.188229 \\ & (0.09404) & (0.14898) & (0.07236) \\ \text { D(EXR_Q) } & 0.065133 & -0.203916 & -0.061152 \\ & (0.06597) & (0.10452) & (0.05077)\end{array}$




\section{Annex III: Granger Causality Tests}

\section{Annual Data}

Pairwise Granger Causality Tests

Date: 02/20/11 Time: 16:21

Sample: 19602009

Lags: 2

\begin{tabular}{lcccc}
\hline \hline Null Hypothesis: & Obs & F-Statistic & Prob. \\
\hline \hline $\begin{array}{l}\text { BD does not Granger Cause CA } \\
\text { CA does not Granger Cause BD }\end{array}$ & 48 & $\begin{array}{l}4.13706 \\
1.36973\end{array}$ & $\begin{array}{l}0.0227 \\
0.2650\end{array}$ \\
\hline \hline INR does not Granger Cause CA & 48 & 1.90753 & 0.1608 \\
CA does not Granger Cause INR & & 0.09888 & 0.9061 \\
\hline \hline EXR does not Granger Cause CA & 48 & 0.36402 & 0.6970 \\
CA does not Granger Cause EXR & & 0.35904 & 0.7004 \\
\hline \hline INR does not Granger Cause BD & 48 & 0.22798 & 0.7971 \\
BD does not Granger Cause INR & & 0.89836 & 0.4147 \\
\hline \hline EXR does not Granger Cause BD & 48 & 0.09791 & 0.9069 \\
BD does not Granger Cause EXR & & 0.54508 & 0.5837 \\
\hline \hline EXR does not Granger Cause INR & 48 & 0.10401 & 0.9014 \\
INR does not Granger Cause EXR & & 1.80087 & 0.1774 \\
\hline \hline
\end{tabular}




\section{Quarterly Data}

Pairwise Granger Causality Tests

Date: 02/21/11 Time: 15:50

Sample: 1990Q1 2009Q4

Lags: 2

\begin{tabular}{lccc}
\hline \hline Null Hypothesis: & Obs & F-Statistic & Prob. \\
\hline \hline BD_Q does not Granger Cause CA_Q & 78 & 0.37879 & 0.0360 \\
CA_Q does not Granger Cause BD_Q & & 0.42041 & 0.6584 \\
\hline \hline EXR_Q does not Granger Cause CA_Q & 78 & 3.74480 & 0.0283 \\
CA_Q does not Granger Cause EXR_Q & & 0.45063 & 0.6390 \\
\hline \hline INR_Q does not Granger Cause CA_Q & 78 & 1.38235 & 0.2575 \\
CA_Q does not Granger Cause INR_Q & & 1.93382 & 0.1519 \\
\hline \hline EXR_Q does not Granger Cause BD_Q & 78 & 0.02640 & 0.9740 \\
BD_Q does not Granger Cause EXR_Q & & 0.70395 & 0.4980 \\
\hline \hline INR_Q does not Granger Cause BD_Q & 78 & 1.06949 & 0.3485 \\
BD_Q does not Granger Cause INR_Q & & 1.35999 & 0.2631 \\
\hline \hline INR_Q does not Granger Cause EXR_Q & 78 & 1.27806 & 0.2847 \\
EXR_Q does not Granger Cause INR_Q & & 1.26706 & 0.2878 \\
\hline \hline
\end{tabular}

